\title{
Differences across the ITCZ in the chemical characteristics of the Indian Ocean MBL aerosol during INDOEX
}

\author{
M. Norman, C. Leck, and H. Rodhe \\ Department of Meteorology, Stockholm University, S-106 91 Stockholm, Sweden \\ Received: 5 October 2002 - Published in Atmos. Chem. Phys. Discuss.: 6 December 2002 \\ Revised: 17 March 2003 - Accepted: 12 May 2003 - Published: 28 May 2003
}

\begin{abstract}
The water soluble inorganic part of the submicrometer aerosol was measured from two research vessels over the Indian Ocean during the winter monsoon season (February and March) as part of the INDOEX project in 1998 and 1999. Additional measurements were made of gas phase $\mathrm{SO}_{2}$ from one of the vessels in 1999. All samples collected north of the Inter Tropical Convergence Zone, ITCZ, were clearly affected by continental, anthropogenic sources. A sharp transition occurred across the ITCZ with concentrations of nss- $\mathrm{SO}_{4}^{2-}, \mathrm{NH}_{4}^{+}$and nss- $\mathrm{K}^{+}$being lower by a factor of 7-15, > 20 and $>40$, respectively, on the southern side of the ITCZ. The contribution from DMS to the sub-micrometer nss- $\mathrm{SO}_{4}^{2-}$ was estimated to be up to $40 \%$ in clean air north of the ITCZ but less than $10 \%$ in polluted air originating from India. South of the ITCZ virtually all nss- $\mathrm{SO}_{4}^{2-}$ was likely to be derived from oxidation of DMS. The concentration of $\mathrm{SO}_{2}$ decreased rapidly with distance from the Indian coast, the molar ratio $\mathrm{SO}_{2} / \mathrm{nss}-\mathrm{SO}_{4}^{2-}$ reaching values below $5 \%$ after $35 \mathrm{~h}$ travel time over the ocean. Surprisingly, MSA, which is derived from DMS, also showed higher concentrations in the sub-micrometer aerosol north of the ITCZ than south of it. This could be explained by the larger sub-micrometer surface area available north of the ITCZ for the condensation of MSA. South of the ITCZ a major part of the MSA was found on the super-micrometer particles. An analysis based on the air trajectories showed that systematic variation in the observed concentrations was associated with variations in the transport from source regions. For example, differences in time since air parcels left the Arabian or Indian coasts was shown to be an important factor for explaining the substantial differences in absolute concentrations.
\end{abstract}

Correspondence to: M. Norman (norman@misu.su.se)

\section{Introduction}

Aerosols have been found to have a large influence on the radiative properties of the Earth's atmosphere both by the direct scattering of the incoming solar radiation (Charlson et al., 1992) and indirectly by changing the properties of clouds present in the atmosphere (Twomey, 1974; IPCC, 2001). Anthropogenic activities have substantially increased the amount of aerosols present in the atmosphere and the climate effects of the anthropogenic aerosols have received large attention due the magnitude and large uncertainties of their climatic effects (IPCC, 2001). In order to reduce these uncertainties, measurements of the aerosol physical and chemical properties are needed to trace the nature, location and strength of the sources as well as to understand their physical and chemical transformation processes occurring in the atmosphere.

The Indian Ocean during January to March is a suitable location to investigate the effects of continental and anthropogenic aerosol against a background marine aerosol. Large emissions of aerosols and aerosol precursors from fossil fuel combustion (Arndt et al., 1997), biomass burning (Galanter et al., 2000) as well as soil dust (Tegen and Fung, 1994) take place over India and neighbouring countries. These aerosol particles and gases are transported with the northeasterly trade winds, mainly in the lower troposphere, out over the Indian Ocean. In addition there are large emissions of soil dust from the continental areas north and northwest of the Arabian Sea (Tegen and Fung, 1994), which are subsequently advected out over the Arabian sea. These two major airflows converge over the Indian Ocean and continue southwards. At the ITCZ (usually located between the equator and $10^{\circ} \mathrm{S}$ at the time of the year, Landsberg, 1984), the polluted air will meet pristine marine air containing aerosols mainly from natural marine sources, including sea spray and dimethyl sulfide (DMS). 
Table 1. Sampling periods and start and stop positions for the three cruises included in this study. Coordinates are Male, Maldives, $4.1^{\circ} \mathrm{N}$, $73.3^{\circ} \mathrm{E}$; Port Louise, Mauritius, $20.2^{\circ} \mathrm{S}, 57.5^{\circ} \mathrm{E}$; Panjim, India, $15.7^{\circ} \mathrm{N}, 73.9^{\circ} \mathrm{E}$; Goa, India, $18.2^{\circ} \mathrm{N}, 73.4^{\circ}$

\begin{tabular}{llllll}
\hline & & Start date & Start position & stop date & stop position \\
\hline $\begin{array}{l}\text { Sagar Kanya 1998 } \\
\text { (SK 1998) }\end{array}$ & Leg 1 & 1 Mar., DOY 60 & Male & 12 Mar., DOY 71 & Port Louise \\
& Leg 2 & 15 Mar., DOY 74 & Port Louise & 30 Mar., DOY 89 & Goa \\
$\begin{array}{llllll}\text { Sagar Kanya 1999 } \\
\text { (SK 1999) }\end{array}$ & Leg 1 & 21 Jan., DOY 21 & Panjim & 10 Feb., DOY 41 & Port Louise \\
& Leg 2 & 18 Feb., DOY 49 & Port Louise & 10 Mar., DOY 69 & Panjim \\
$\begin{array}{lllll}\text { Ronald H Brown 1999 } \\
\text { (RB 1999) }\end{array}$ & Leg 1 & 22 Feb., DOY 53 & Port Louise & 28 Feb., DOY 59 & Male \\
& Leg 2 & 4 Mar., DOY 63 & Male & 23 Mar., DOY 82 & Male \\
& Leg 3 & 26 Mar., DOY 85 & Male & 30 Mar., DOY 89 & Male \\
\hline
\end{tabular}

The Indian Ocean experiment, INDOEX, was performed over the Indian Ocean during the Asian winter monsoon season January-March. Two of the main objectives were to asses the role of the ITCZ in the transport of aerosols and gases and to study the importance of sulfate and other continental aerosol components for the radiative forcing over the Indian Ocean (Ramanathan et al., 1996). The INDOEX campaign began with ship and land based observations in 19951997 and was intensified during a First Field Phase (FFP) during 1998 (Mitra, 1999) and culminated with the Intensive Field Phase (IFP) during 1999 which included a large variety of platforms and measurements (Ramanathan et al., 2001). References to several detailed studies carried out as part of INDOEX are given in Sect. 3.

In this study we present results from ship based measurements of the concentration and relative chemical composition of the water soluble inorganic fraction of the aerosol in the Marine boundary layer (MBL). The measurements were performed over the Indian Ocean during the FFP in 1998 and the IFP 1999. In addition, measurements of gas phase sulfur dioxide $\left(\mathrm{SO}_{2}\right)$ were performed during the IFP 1999. Our specific goals were (i) to study the role of the ITCZ in the transport of marine boundary layer aerosol and $\mathrm{SO}_{2}$ over the Indian Ocean, (ii) to investigate the variation in concentration and relative chemical composition of the aerosol in relation to the air mass origin (iii) and to investigate the interannual difference of the aerosol between the 1998 and 1999.

\section{Method}

\subsection{Cruise track and observing periods}

The measurements were performed on board the US research vessel Ronald H. Brown during the IFP 1999 and on board the Indian research vessel Sagar Kanya during both the FFP 1998 and the IFP 1999. In total three cruises were performed, the Sagar Kanya 1998 (SK 1998) consisting of two Legs, the Sagar Kanya 1999 (SK 1999) also consisting of two Legs and the Ronald H. Brown 1999 (RB 1999) consisting of three Legs. Table 1 shows the sampling periods together with the start and end locations of each Leg. Figure 1 shows the cruise tracks for the cruises.

\subsection{Sampling}

\subsubsection{Particulate phase}

The collection of particulate mass on board Ronald $\mathrm{H}$. Brown was made from an intake located at the top of a $6 \mathrm{~m}$ mast in front of the bridge. The height of the collection point was $18 \mathrm{~m}$ above sea level.

Ambient sub-micron aerosol mass (here referred to as fpm) was determined using a filter pack set (flow rate $50 \mathrm{dm}^{-3} \mathrm{~min}^{-1}$ ) mounted on a sliding tray next to the entrance of the mast. The set held three units: two of them collected samples and one served as a sampling and an analytical blank. The size of the sampled particles (aerodynamic diameter, EAD, $<0.9 \mu \mathrm{m}$ ) was determined by using a cyclone in front of each filter unit (Quinn and Bates, 1989). Each of the units consisted of one $47 \mathrm{~mm}$ Millipore Teflon aerosol particle filter with $1.0 \mu \mathrm{m}$ pore size held in a polyacetal (Deldrin $($ ) filter holder. More details are given in Leck and Persson (1996). Each sample prolonged for about $6 \mathrm{~h}$.

In order to limit the sampling to periods of clean air, the pumps to the aerosol sampling systems were controlled by the ship's pollution sensor (Quinn et al., 2001). The sample air was considered to be free of ship contamination or influence from other ships in the surroundings when the relative wind speed was greater than $3 \mathrm{~ms}^{-1}$ and forward of the beam and with no rapid increase in number concentration of particles greater than $15 \mathrm{~nm}$ in diameter. The particle number limit was set manually to a few hundred per cubic centimeter above the ambient particle concentration. The pumps were switched off due to pollution for less than $5 \%$ of the total sampling time.

The same setup for ambient sub-micron aerosol was used on board the Sagar Kanya, but the control system for 


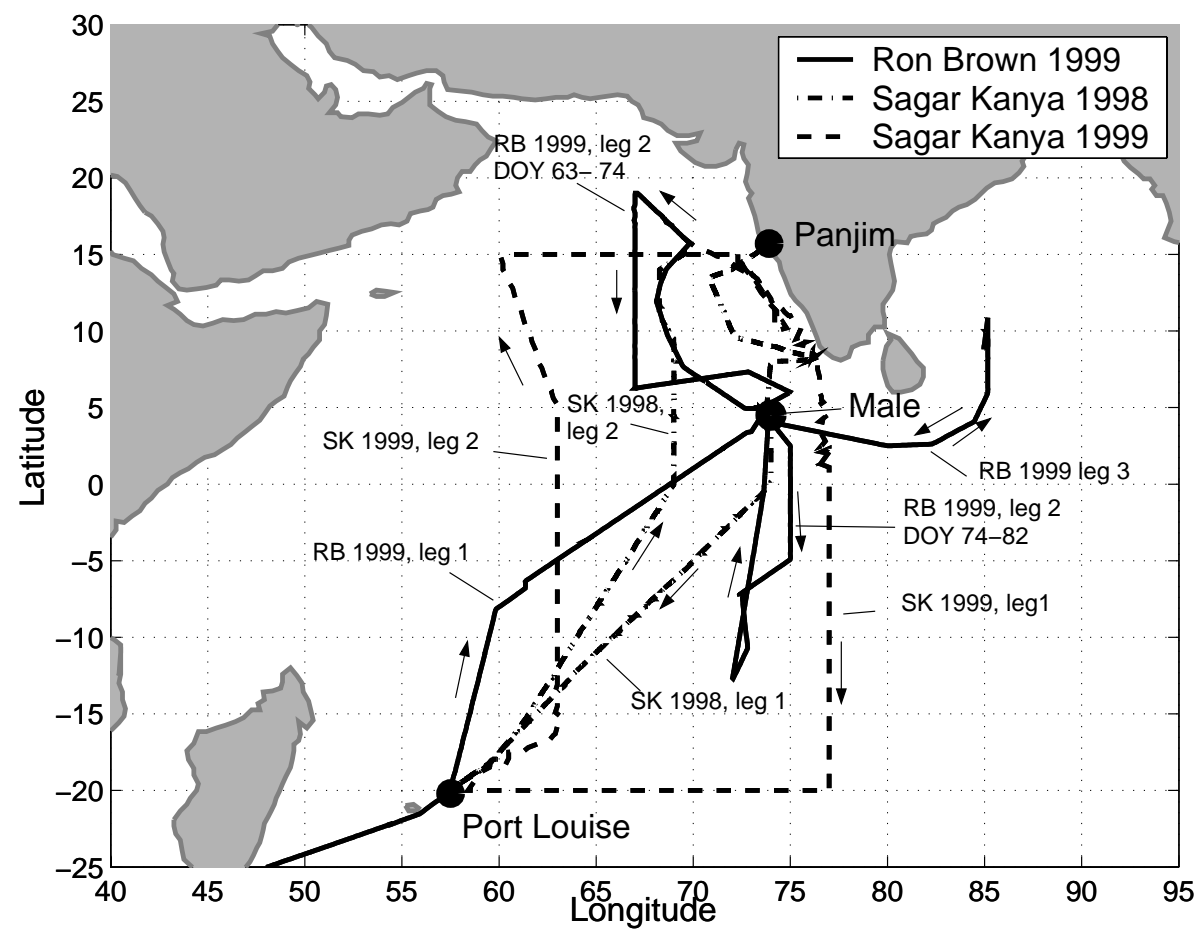

Fig. 1. Cruise tracks for the Ronald H. Brown 1999 cruise and the Sagar Kanya 1998 and 1999 cruises. The arrows along the cruise tracks show the traveling direction of the ship.

avoiding contamination was limited to wind speed and wind direction only.

\subsubsection{Gas phase $\mathrm{SO}_{2}$}

The measurements of $\mathrm{SO}_{2}$ was performed with an automated real-time modified Saltzman et al. (1993) technique involving high pressure liquid chromatography with fluorescence detection. The air was sampled (flow rate $6 \mathrm{dm}^{3} \mathrm{~min}^{-1}$ ) from a heated sampling line with a total flow rate of $50 \mathrm{dm}^{3} \mathrm{~min}^{-1}$. The $0.9 \mu \mathrm{m}$ EAD inlet used the same type of cyclone as for the fpm sampling. The inlet was placed next to the aerosol inlets and with a teflon tubing running parallel to the aerosol sampling line. To further reduce potential surface particle losses the air was dried by a Nafion dryer and subsequently drawn through a filter to remove particles. Calibration was performed with gas phase calibration using a permeation device with known emission at a specific temperature. The gas was diluted with controlled flow of zero gas to different concentrations. The detection limit was 5 pptv with accuracy of $20 \%$ and examples of observed reproducibility were $43.2 \pm 2.5 \mathrm{pptv}(5.7 \%)$ and $21.1 \pm 0.9 \mathrm{pptv}(4.5 \%)$.

\subsection{Analysis of particulate matter}

All filter substrate, samples and blanks were carefully handled in a glove box (free from particles and gases such as ammonia $\left(\mathrm{NH}_{3}\right)$ and $\left.\mathrm{SO}_{2}\right)$ both prior to and after collection.
After exposure all filters and substrates were extracted (inside the glove box) by wetting with $0.5 \mathrm{~cm}^{3}$ methanol and $4.5 \mathrm{~cm}^{3}$ deionized water (Millipore Alpha-Q, $18 \mathrm{M} \Omega \mathrm{cm}$ ). The extracts were then analyzed for major cations, major anions and methane sulfonate $\left(\mathrm{CH}_{3} \mathrm{SOO}^{-}\right.$, MSA) using chemically suppressed IC. The analysis of cations used Dionex CG12A/CS12A column and a CRSR-I auto suppressor. Strong anions were analyzed with a DIONEX AG4A/AS4A column and a CSRS-1 membrane suppressor. MSA was analyzed with a Dionex AG4/AS4 column using a stepwise elution. A Dionex ATC-1 column was used prior to the injection valve in order to retain ionic contaminants in the eluent during the run. More details are given in Quinn et al. (1998).

The average blank concentrations in the extracts were zero for MSA and sulfate $\left(\mathrm{SO}_{4}^{2-}\right), 0.22 \pm 0.44 \mu \mathrm{eq} \mathrm{dm}{ }^{-3}$ (given as one $\sigma$ ) for nitrate $\left(\mathrm{NO}_{3}^{-}\right), 1.7 \pm 0.94$ for chloride $\left(\mathrm{Cl}^{-}\right), 2.6 \pm$ 1.2 for sodium $\left(\mathrm{Na}^{+}\right), 0.34 \pm 0.27$ for ammonium $\left(\mathrm{NH}_{4}^{+}\right)$, $0.24 \pm 0.12$ for potassium $\left(\mathrm{K}^{+}\right), 0.24 \pm 0.25$ for magnesium $\left(\mathrm{Mg}^{2+}\right)$ and $0.99 \pm 0.61$ for calcium $\left(\mathrm{Ca}^{2+}\right)$.

The average blank to sample fractions were $<5 \%$ for $\mathrm{NH}_{4}^{+},<10 \%$ for $\mathrm{NO}_{3}^{-}$and $\mathrm{K}^{+},<15 \%$ for $\mathrm{Mg}^{2+}$ and $<30 \%$ for $\mathrm{Na}^{+}, \mathrm{Cl}^{-}$and $\mathrm{Ca}^{2+}$. The average blank concentrations were subtracted from all samples. Duplicate samples agreed on average, within $25 \%$.

Non-sea-salt (nss) concentrations of $\mathrm{SO}_{4}^{2-}, \mathrm{K}^{+}$and $\mathrm{Ca}^{2+}$ were calculated using molar ratios to $\mathrm{Na}^{+}$or $\mathrm{Mg}^{2+}$ (when 

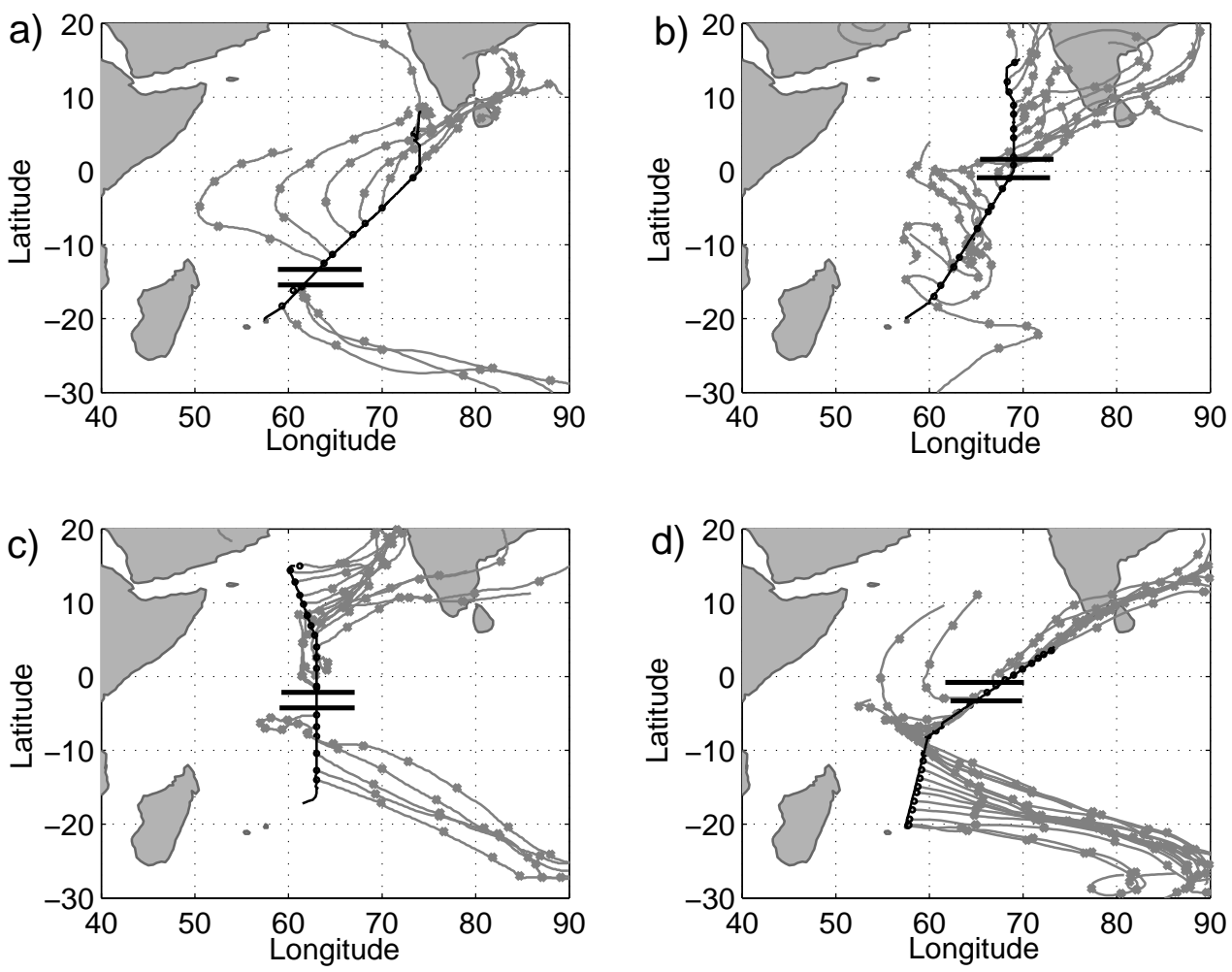

Fig. 2. Cruise tracks and trajectories during the four ITCZ passages. (a) Sagar Kanya 1998 southwards during Leg 1 (SK 1998 south), (b) Sagar Kanya 1998 northwards during Leg 2 (SK 1998 north), (c) Sagar Kanya 1999 northwards during Leg 2 (SK 1999 north), (d) Ronald H. Brown 1999 northwards during Leg 1 (RB 1999 north). The ITCZ was identified both by trajectories and meteorological observations on board the ships and the ITCZ is marked with double solid lines in each figure.

no $\mathrm{Na}^{+}$data were available) in sea water taken from Wilson (1975). All concentrations for the particulate matter and gas phase have been converted to standard atmosphere temperature and pressure (STP, temperature $0^{\circ}$ Celsius and pressure $1013.2 \mathrm{hPa}$ ) by using observed temperature and pressure such that $1 \mathrm{nmol} \mathrm{m}^{-3}$ equals $22.4 \mathrm{pptv}$.

\subsection{Trajectories and supporting meteorological data}

\subsubsection{Trajectories}

Air mass back trajectories were calculated for the Ronald H. Brown cruise during IFP 1999 for the arrival height of $500 \mathrm{~m}$ at the ship position every six hours. The trajectories were calculated with the hybrid single-particle Langrangian integrated model HY-SPLIT 4 based on global wind fields (Draxler, 1992). Trajectories for the Sagar Kanya cruises 1998 and 1999 were calculated for the arrival height of 950 $\mathrm{hPa}(\sim 500 \mathrm{~m})$ and at the ship position for the center time for each filterpack sample. The trajectories were calculated with the McGrath (1989) model at the European Center of Medium-range Weather Forecasts (ECMWF) using their analyzed wind and pressure fields. All trajectories were calculated for a time period of seven days backward in time.
A comparison between the two trajectory models showed that the difference was small $(<500 \mathrm{~km})$ for the first $100 \mathrm{~h}$ backwards in time and that the mean difference never exceeded $1000 \mathrm{~km}$ for the whole 7 days calculated period.

For each trajectory the time since last contact with land areas (India ( $\left.T_{\text {Ind }}\right)$, land areas around the Arabian Sea ( $\left.T_{\text {Arab }}\right)$ and any land area $\left(T_{\text {land }}\right)$ ) was estimated by following the trajectories backwards from the position of the ship until they reached the coastline.

\subsubsection{Supporting data}

Meteorological parameters including surface temperature, relative humidity $(\mathrm{RH})$, wind speed and wind direction (both relative and absolute), pressure and short wave radiation were measured on board both Ronald H. Brown and Sagar Kanya. The height of the well mixed MBL from the RB 1999 cruise was defined from soundings as the top of the lowest cloud layer, or at cloud free conditions, the level where the relative humidity rapidly decreased. The MBL height usually ranged between 800 and $2000 \mathrm{~m}$ which ensured that the arrival height of the trajectories were in the MBL. During periods with strong vertical mixing, like within the ITCZ during 
leg 1 and within a thunder storm during leg 3, the soundings showed the atmosphere to be humid up to $6 \mathrm{~km}$.

\section{Influence of the ITCZ on the Indian Ocean MBL aerosol and $\mathrm{SO}_{2}$}

To assess the role of ITCZ in the transport of trace constituents and pollutants over the Indian Ocean, this study included four separate cross ITCZ transects: Sagar Kanya 1998 southwards during Leg 1 (SK 1998 south), Sagar Kanya 1998 northwards during Leg 2 (SK 1998 north), Sagar Kanya 1999 northwards during Leg 2 (SK 1999 north) and Ronald H. Brown 1999 northwards during Leg 1 (RB 1999 north). Figure 2 shows the cruise tracks. Also shown are the calculated trajectories for each transect and the position of the ITCZ. The location of the ITCZ was identified both by the trajectories and meteorological observations like wind direction, wind speed, cloud observations and the soundings. The concentrations of fpm for selected water-soluble components as a function of latitude relative to the ITCZ are presented in Fig. 3. The concentrations were normalized such that the median concentrations north of the ITCZ were set equal to one for each transect. Figure $3 \mathrm{a}$ shows that the sum of the analyzed fpm had a marked change in concentration at the position of the ITCZ. This applied to all four passages, although the median concentration ratio between north of the ITCZ and south of the ITCZ varied between 6 and 14. As seen in Figs. 3b-d a similar sharp concentration increase was observed for constituents with typical anthropogenic or continental sources like nss- $\mathrm{SO}_{4}^{2-}$ mainly from fossil fuel combustion, $\mathrm{NH}_{4}^{+}$from agriculture and nss- $\mathrm{K}^{+}$from biomass burning. The fpm $\mathrm{NO}_{3}^{-}$was only observed in concentrations close to the detection limit and will not be further discussed. The north/south ratios for nss- $\mathrm{SO}_{4}^{2-}, \mathrm{NH}_{4}^{+}$and nss- $\mathrm{K}^{+}$range between 6-16, 20-80 times and above 40, respectively. The relative larger concentration differences observed for nss- $\mathrm{K}^{+}$ and $\mathrm{NH}_{4}^{+}$are consistent with their relatively weaker natural sources over the ocean (Quinn et al., 1992; Saxena, 1983) compared to that of nss-SO $\mathrm{SO}_{4}^{2-}$ (Ayers et al., 1996). The fpm soil dust influence, here represented by nss- $\mathrm{Ca}^{2+}$, also showed slightly enhanced concentration north of the ITCZ. However, Fig. 3e shows that the variation was high and the south-north difference was not significant. No significant south-north trend was observed in the sea salt components, derived from chloride plus sodium to sea salt mass ratio in sea water using Wilson (1975) ratios, see Fig. 3f. No significant important gradients in any of the meteorological parameters (including MBL height, $\mathrm{RH}$, wind speed, temperature and precipitation frequency) were observed. This suggests that the observed south north gradient for constituents of anthropogenic origin not was primarily caused by differences in meteorological factors. We conclude that the different origin of the air north respectively south of the ITCZ was the reason for the observed differences.
A somewhat striking result was the high concentration of fpm MSA observed in the samples collected north of the ITCZ, Fig. 4a. Total analyzed MSA (fpm (this study) + coarse particulate mass, cpm, (Quinn et al., 2002), Fig. 4c, showed MSA south of the ITCZ to be about half of those observed north of ITCZ. Cpm MSA was found to be below detection limit north of the ITCZ, Fig. 4b. The only source of particulate MSA is the oxidation from DMS in the atmosphere (Saltzman et al., 1983). However, when comparing with the observed DMS concentrations, both in air and in sea water (only available for Ronald $\mathrm{H}$. Brown cruise), no indication of higher concentrations north of the ITCZ was recorded (Bates 2002, unpublished data). Variation in the DMS concentration could therefore be ruled out as the cause of the observed gradient in the MSA across the ITCZ. According to Yin et al. (1990), formaldehyde ( $\mathrm{HCHO})$ and ozone $\left(\mathrm{O}_{3}\right)$ are important oxidants in the DMS oxidation scheme and thus important for the production of MSA. Substantially higher concentrations of $\mathrm{HCHO}$ (Wagner et al., 2001) and $\mathrm{O}_{3}$ (Stehr et al., 2002) were observed on board the RB 1999 north of the ITCZ. This would have lead to an increased production of particulate MSA in the polluted air independent of the particle size. However, as this was not the case the higher oxidant levels observed north of ITCZ were suggested not to be the major cause of the elevated levels of fpm MSA found. Kerminen and Leck (2001) calculated that the condensation of gas phase MSA will favor the aerosol size range with the largest available surface area. During the RB 1999 north transect the aerosol area size distributions were dominated by the coarse mode in samples collected south of the ITCZ while the sub-micrometer aerosol dominated in the air originating from India (Bates et al., 2002). The available aerosol surface might then explain not only the higher fpm MSA observed north of ITCZ, but also the higher cpm MSA observed in the clean air south of ITCZ.

During the INDOEX IFP 1999 several additional measurements of aerosol and gaseous components were performed. For a direct comparison with this study one ITCZ cross transect is available (RB 1999 north). Ball et al. (2003) and Quinn et al. (2002) reported results of the fpm watersoluble ionic composition in good agreement with the present study. This is reassuring since different sampling and analytical techniques were applied. A similar south/north gradient was also found for fpm organic carbon and elemental carbon across the ITCZ (Neusüss et al., 2002). Measurements of cloud condensation nuclei during FFP 1998 (Cantrell at al., 2000) also showed a similar marked north/south gradient indicating the climatic relevance of these results.

Measurements of gases with anthropogenic origin, like carbon monoxide $(\mathrm{CO})$ and $\mathrm{O}_{3}$, also showed substantially higher concentrations north of the ITCZ on board the Ronald H. Brown during IFP 1999, as observed by Stehr et al. (2002). The difference was smaller for gases than for aerosols. In contrast to the parameters discussed above, measurements of $\mathrm{SO}_{2}$ during the RB 1999 north, Fig. 5, did not 


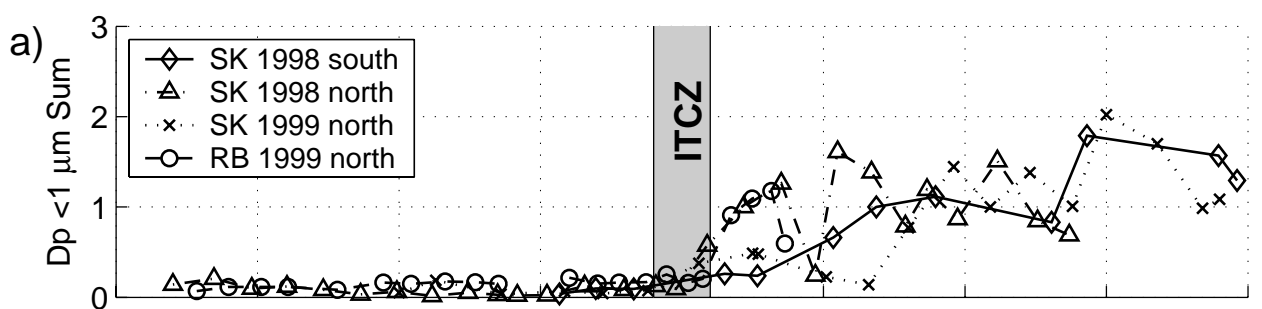

b)

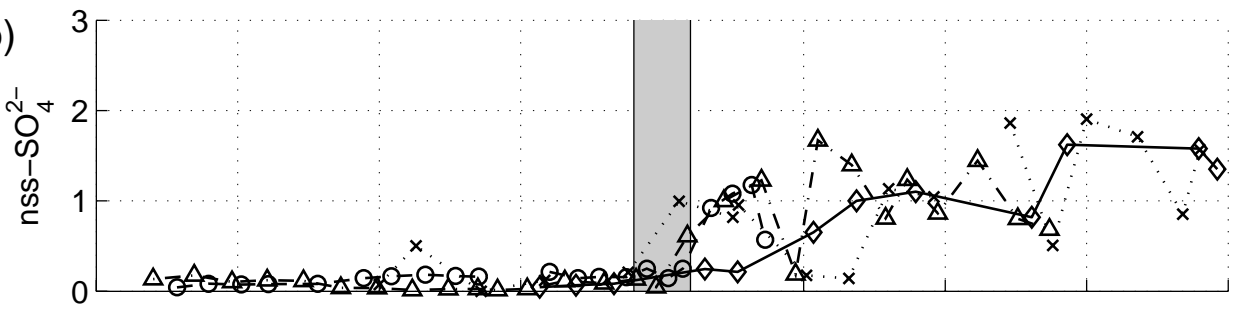

c)

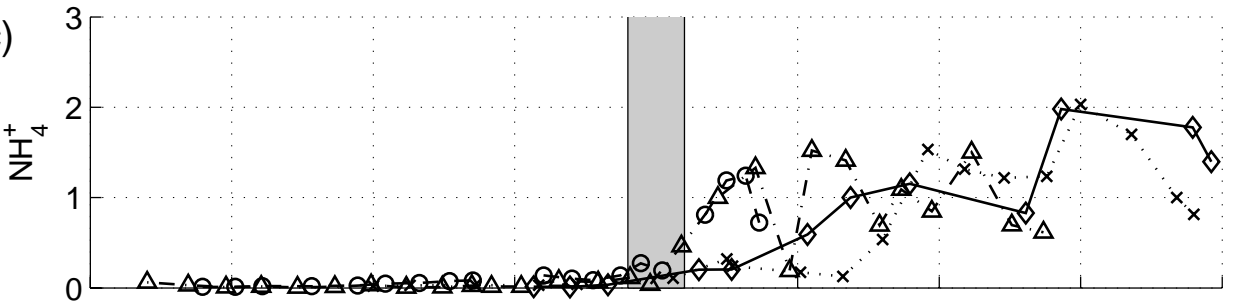

d)

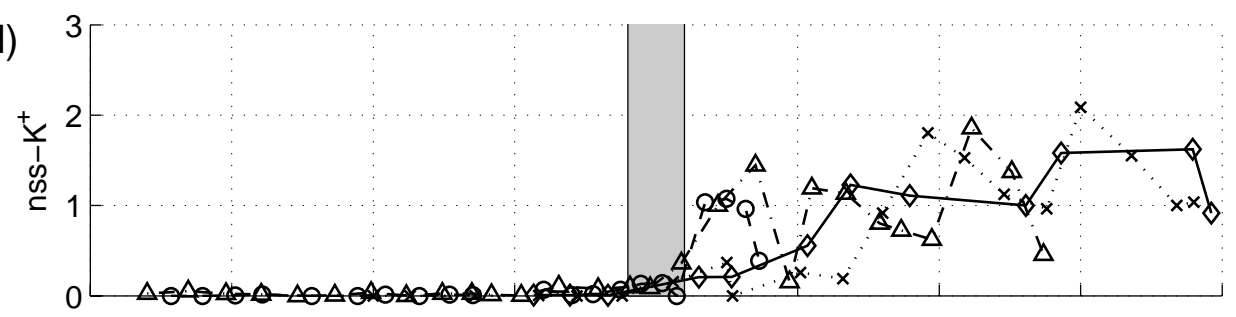

e)
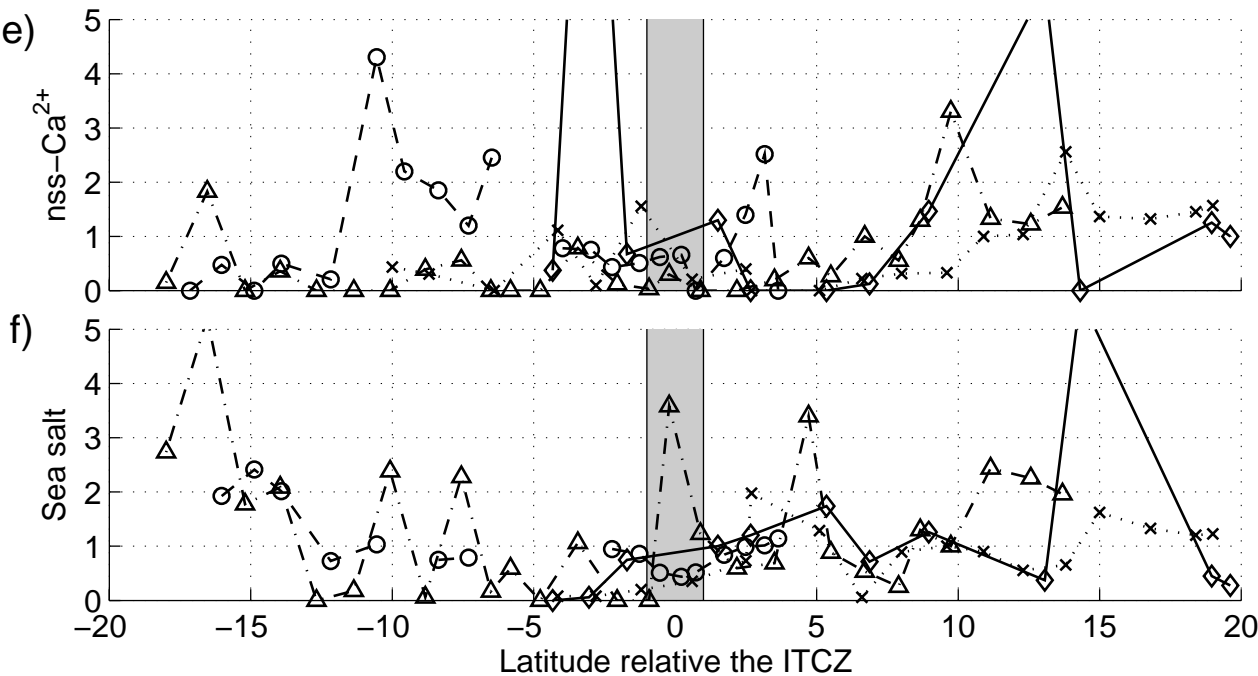

Fig. 3. The mass concentration of the fpm aerosol during the cross ITCZ passages as a function of latitude relative to the ITCZ. The concentrations are normalized to the median concentration north of the ITCZ for each passage. SK = Sagar Kanya and RB = Ronald H. Brown. 
a)

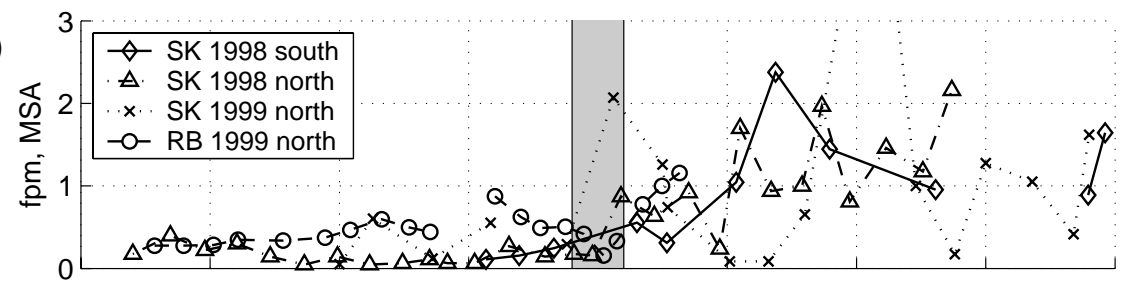

b)
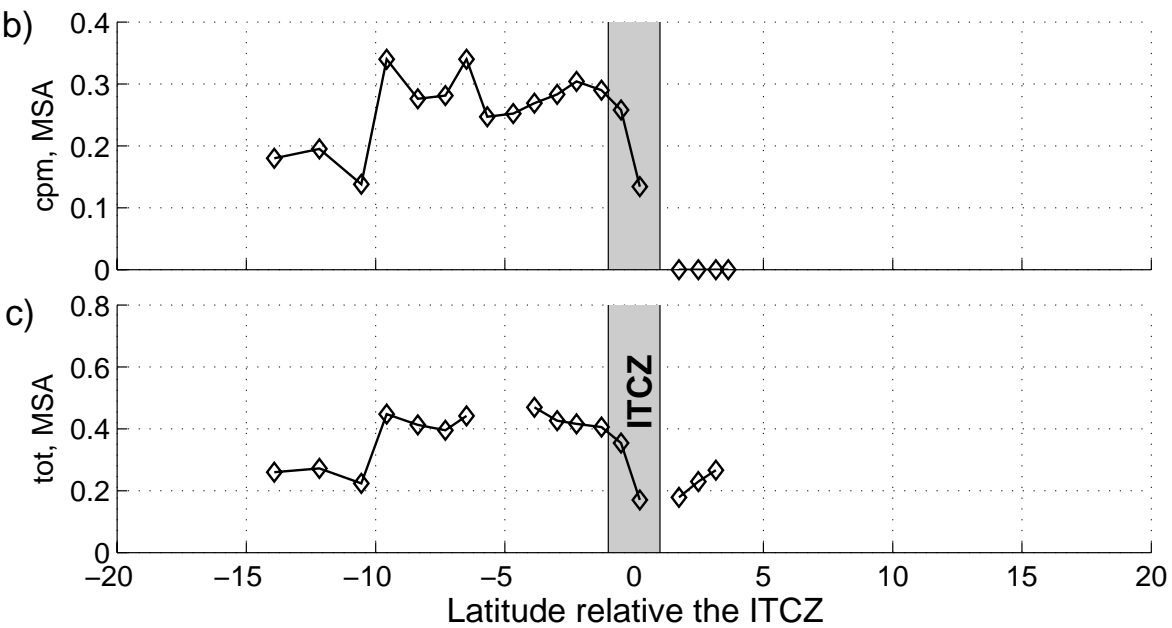

Fig. 4. (a) The mass concentration of MSA during the four cross ITCZ passage. The concentrations are normalized to the median concen-

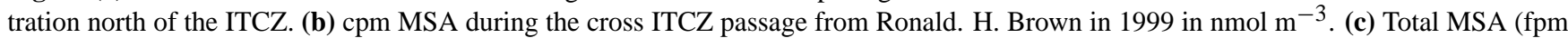
$+\mathrm{cpm}$ ) during the cross ITCZ passage from Ronald. H. Brown in $1999 \mathrm{in} \mathrm{mmol} \mathrm{m}{ }^{-3}$. The latitude is given as a function of latitude relative to the ITCZ.

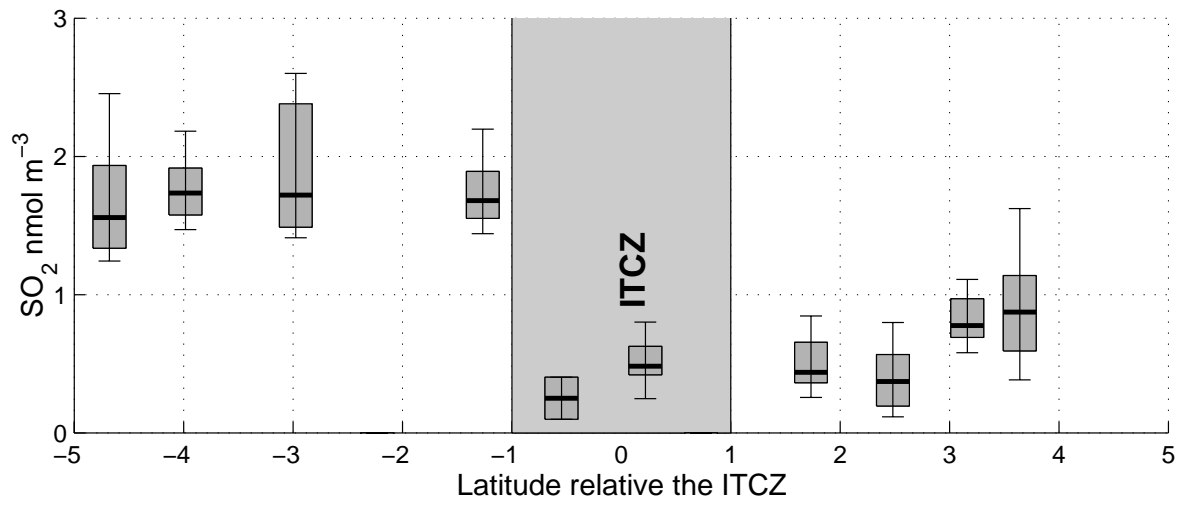

Fig. 5. The concentration of $\mathrm{SO}_{2}$ across the ITCZ during the RB 1999 north as medians over the aerosol sampling time ( $\left.\sim 6 \mathrm{~h}\right)$. The box includes data between the 25 and 75 percentiles and the vertical bars represent the 10 and 90 percentiles. 
Table 2. The fpm 25, 50 and 75 percentile concentrations and molar ratios for the different trajectory groups from the Ronald H. Brown cruise in 1999. The North ITCZ group includes all trajectories in the cleanN, Arab, sInd and IInd groups. The time since last contact with land refers to any land $\left(\mathrm{T}_{\text {land }}\right)$ for cleanN, cleanS and North ITCZ, to India $\left(\mathrm{T}_{\text {Ind }}\right)$ for sInd and IInd and to other land than India $\left(\mathrm{T}_{A r a b}\right)$ for Arab. Sea salt was calculated as chloride plus sodium total sea salt mass ratio in sea water using Wilson (1975) ratios

\begin{tabular}{|c|c|c|c|c|c|c|c|c|c|c|}
\hline & & $\begin{array}{l}\text { MSA } \\
\text { nmol } \\
\mathrm{m}^{-3}\end{array}$ & $\begin{array}{l}\mathrm{CI}^{-} \\
\mathrm{nmol} \\
\mathrm{m}^{-3}\end{array}$ & $\begin{array}{l}\mathrm{NO}_{3}^{-} \\
\mathrm{nmol} \\
\mathrm{m}^{-3}\end{array}$ & $\begin{array}{l}\mathrm{NA}^{+} \\
\mathrm{nmol} \\
\mathrm{m}^{-3}\end{array}$ & $\begin{array}{l}\mathrm{NH}_{4}^{+} \\
\mathrm{nmol} \\
\mathrm{m}^{-3}\end{array}$ & $\begin{array}{l}\mathrm{Mg}^{2+} \\
\mathrm{nmol} \\
\mathrm{m}^{-3}\end{array}$ & $\begin{array}{l}\mathrm{nss}^{-\mathrm{SO}_{4}^{2-}} \\
\mathrm{nmol} \\
\mathrm{m}^{-3}\end{array}$ & $\begin{array}{l}\mathrm{nss}-\mathrm{Ca}^{2+} \\
\mathrm{nmol} \\
\mathrm{m}^{-3}\end{array}$ & $\begin{array}{l}\text { nss-K } \\
\text { nmol } \\
\mathrm{m}^{-3} \\
\end{array}$ \\
\hline \multirow[t]{3}{*}{ cleanS } & $25 \mathrm{prc}$ & 0.07 & 0.68 & $<\mathrm{DL}$ & 1.2 & 0.4 & 0.05 & 2.3 & 0.15 & $<\mathrm{DL}$ \\
\hline & $50 \mathrm{prc}$ & 0.09 & 1.2 & $<\mathrm{DL}$ & 1.3 & 1.1 & 0.17 & 4.1 & 0.33 & 0.04 \\
\hline & $75 \mathrm{prc}$ & 0.12 & 2.5 & 0.08 & 2.5 & 2.3 & 0.43 & 4.8 & 0.87 & 0.08 \\
\hline North & $25 \mathrm{prc}$ & 0.14 & $<\mathrm{DL}$ & 0.07 & 0.9 & 22.6 & 0.10 & 12.9 & 0.19 & 1.4 \\
\hline \multirow[t]{2}{*}{ ITCZ } & $50 \mathrm{prc}$ & 0.21 & 0.25 & 0.27 & 1.6 & 35.6 & 0.26 & 23.6 & 0.50 & 3.7 \\
\hline & 75 prc & 0.26 & 0.52 & 0.47 & 2.3 & 53.0 & 0.37 & 39.5 & 0.88 & 6.5 \\
\hline \multirow[t]{3}{*}{ cleanN } & $25 \mathrm{prc}$ & 0.14 & 0.24 & $<\mathrm{DL}$ & 0.5 & 6.8 & 0.07 & 6.1 & 0.08 & 0.48 \\
\hline & $50 \mathrm{prc}$ & 0.21 & 0.60 & 0.09 & 1.1 & 22.6 & 0.10 & 11.5 & 0.15 & 1.4 \\
\hline & 75 prc & 0.26 & 1.1 & 0.19 & 1.7 & 32.7 & 0.19 & 16.5 & 0.20 & 3.1 \\
\hline \multirow[t]{3}{*}{ Arab } & $25 \mathrm{prc}$ & 0.13 & $<\mathrm{DL}$ & 0.19 & 1.1 & 23.5 & 0.17 & 13.1 & 0.39 & 1.2 \\
\hline & $50 \mathrm{prc}$ & 0.18 & 0.3 & 0.41 & 1.8 & 35.5 & 0.35 & 23.6 & 0.63 & 3.2 \\
\hline & 75 prc & 0.23 & 0.5 & 0.61 & 2.6 & 48.2 & 0.44 & 30.9 & 1.0 & 4.3 \\
\hline \multirow[t]{3}{*}{ sInd } & $25 \mathrm{prc}$ & 0.14 & 0.01 & $<\mathrm{DL}$ & 0.8 & 20.0 & $<\mathrm{DL}$ & 13.6 & 0.25 & 2.0 \\
\hline & $50 \mathrm{prc}$ & 0.22 & 0.18 & 0.10 & 1.6 & 34.7 & 0.18 & 22.6 & 0.32 & 4.3 \\
\hline & $75 \mathrm{prc}$ & 0.27 & 0.41 & 0.30 & 2.0 & 52.6 & 0.27 & 40.9 & 0.40 & 6.5 \\
\hline \multirow[t]{3}{*}{ IInd } & $25 \mathrm{prc}$ & 0.20 & $<\mathrm{DL}$ & 0.14 & 1.4 & 49.6 & 0.22 & 34.4 & 0.63 & 4.8 \\
\hline & 50 prc & 0.21 & 0.13 & 0.37 & 1.9 & 69.1 & 0.29 & 54.9 & 0.97 & 8.3 \\
\hline & 75 prc & 0.25 & 0.55 & 0.48 & 2.2 & 92.6 & 0.30 & 60.8 & 1.1 & 9.3 \\
\hline
\end{tabular}

\begin{tabular}{|c|c|c|c|c|c|c|c|c|c|c|c|}
\hline & & $\begin{array}{l}\text { Sea } \\
\text { salt } \\
\mu \mathrm{g} \mathrm{m}^{-3}\end{array}$ & $\begin{array}{l}\text { Sum } \\
\mu \mathrm{g} \mathrm{m}^{-3} \\
\text { ratio }\end{array}$ & $\begin{array}{l}\mathrm{CI}^{-} / \\
\mathrm{Na}^{+} \\
\text {molar } \\
\text { ratio }\end{array}$ & $\begin{array}{l}\mathrm{MSA} / \\
\mathrm{nss}^{-S^{2-}} \\
\text { molar } \\
\text { ratio }\end{array}$ & $\begin{array}{l}\mathrm{NH}_{4}^{+} / \\
\mathrm{nss}^{-} \mathrm{SO}_{4}^{2-} \\
\text { molar } \\
\text { ratio }\end{array}$ & $\begin{array}{l}\mathrm{Ca}^{2+} / \\
\mathrm{Na}^{+} \\
\text {molar } \\
\text { ratio } \\
\end{array}$ & $\begin{array}{l}\mathrm{SO}_{2} / \\
\mathrm{SO}_{4}^{2-} \\
\text { molar }\end{array}$ & $\begin{array}{l}\mathrm{SO}_{2} \\
\mathrm{nmol} \\
\mathrm{m}^{-3}\end{array}$ & $\begin{array}{l}\text { Number } \\
\text { of } \\
\text { samples } \\
\text { (h) }\end{array}$ & $\begin{array}{l}\text { Time since } \\
\text { last contact } \\
\text { with land }\end{array}$ \\
\hline \multirow[t]{3}{*}{ cleanS } & $25 \mathrm{prc}$ & 0.060 & 0.4 & 0.67 & 0.023 & 0.2 & 0.11 & 0.36 & 1.3 & 14 & $>170$ \\
\hline & $50 \mathrm{prc}$ & 0.081 & 0.5 & 0.97 & 0.029 & 0.3 & 0.12 & 0.44 & 1.6 & & $>170$ \\
\hline & $75 \mathrm{prc}$ & 0.162 & 0.6 & 1.03 & 0.034 & 0.5 & 0.59 & 0.56 & 2.1 & & $>170$ \\
\hline North & $25 \mathrm{prc}$ & 0.036 & 1.7 & 0.00 & 0.006 & 1.3 & 0.22 & 0.02 & 0.7 & 92 & 76 \\
\hline \multirow[t]{2}{*}{ ITCZ } & $50 \mathrm{prc}$ & 0.059 & 3.2 & 0.13 & 0.008 & 1.4 & 0.34 & 0.05 & 1.1 & & 120 \\
\hline & $75 \mathrm{prc}$ & 0.085 & 5.0 & 0.33 & 0.012 & 1.7 & 0.51 & 0.08 & 1.5 & & $>170$ \\
\hline \multirow[t]{3}{*}{ cleanN } & $25 \mathrm{prc}$ & 0.030 & 1.0 & 0.40 & 0.012 & 1.1 & 0.08 & 0.05 & 0.7 & 18 & $>170$ \\
\hline & $50 \mathrm{prc}$ & 0.054 & 1.6 & 0.58 & 0.019 & 1.5 & 0.16 & 0.10 & 0.9 & & $>170$ \\
\hline & $75 \mathrm{prc}$ & 0.094 & 2.3 & 0.77 & 0.028 & 2.0 & 0.25 & 0.33 & 1.5 & & $>170$ \\
\hline \multirow[t]{3}{*}{ Arab } & $25 \mathrm{prc}$ & 0.033 & 1.9 & $<\mathrm{DL}$ & 0.006 & 1.4 & 0.27 & 0.02 & 0.7 & 43 & 87 \\
\hline & $50 \mathrm{prc}$ & 0.065 & 3.1 & 0.13 & 0.008 & 1.5 & 0.34 & 0.05 & 1.1 & & 120 \\
\hline & $75 \mathrm{prc}$ & 0.095 & 4.1 & 0.23 & 0.009 & 2.3 & 0.53 & 0.08 & 1.4 & & $>170$ \\
\hline \multirow[t]{3}{*}{ sInd } & $25 \mathrm{prc}$ & 0.035 & 1.8 & 0.04 & 0.006 & 1.1 & 0.20 & 0.03 & 0.5 & 18 & 72 \\
\hline & 50 prc & 0.053 & 3.0 & 0.13 & 0.008 & 1.3 & 0.26 & 0.04 & 0.6 & & 165 \\
\hline & $75 \mathrm{prc}$ & 0.069 & 5.4 & 0.35 & 0.012 & 1.5 & 0.42 & 0.08 & 1.0 & & $>170$ \\
\hline \multirow[t]{3}{*}{ IInd } & $25 \mathrm{prc}$ & 0.049 & 4.5 & $<\mathrm{DL}$ & 0.003 & 1.1 & 0.37 & 0.02 & 1.1 & 13 & 35 \\
\hline & 50 prc & 0.056 & 7.6 & 0.06 & 0.004 & 1.5 & 0.49 & 0.02 & 1.5 & & 52 \\
\hline & 75 prc & 0.067 & 8.0 & 0.14 & 0.007 & 1.6 & 0.58 & 0.05 & 2.2 & & 92 \\
\hline
\end{tabular}


show any south to north concentration increase. Instead a $\sim 50 \%$ decrease was recorded. These noticeable results will be further discussed in Sect. 4.1 and 5.1.

All ship based particulate and gaseous measurements ( $\mathrm{SO}_{2}$ not included) were supported by aircraft measurements within the MBL (Reiner et al., 2001; Sprung et al., 2001; Wisthaler et al., 2002). The aircraft measurements showed marked differences in both gas and particulate phase constituents across the ITCZ in the MBL. However the differences in the free troposphere were smaller than in the MBL (Sprung et al., 2001; Reiner et al., 2001). The reason might be that there was a more efficient cross ITCZ transport in the free troposphere than in the MBL, as also indicated by trajectory analysis by Verver et al. (2001). Measurements showed that major parts of the pollution over the Indian Ocean was transported from southern and southeast Asia at altitudes above the MBL with a sea breeze circulation underneath it (Lelieveld et al., 2001; Reiner et al., 2001; de Reus et al., 2001; Leon et al., 2001; Welton et al., 2002). These pollution layers above the MBL might to a small extent have the potential to cross the ITCZ.

As seen in Fig. 2 the geographical position of the ITCZ varied substantially, between $14^{\circ} \mathrm{S}$ to $1^{\circ} \mathrm{N}$, between the four cross ITCZ transects performed during this study. Figure 3 shows that there were no, or only small, cross ITCZ exchange of fpm aerosols in the MBL since the concentrations of continental fpm aerosol components were not elevated in the samples collected just south of the ITCZ. We conclude that the ITCZ should be looked upon as an effective barrier for transport of MBL fpm aerosols during the winter monsoon season over the Indian Ocean. Irrespective of the latitudinal position of the ITCZ, the air north of the ITCZ was influenced by anthropogenic and continental sources whereas the air south of the ITCZ showed no such influence.

In the following sections an effort is made to seek causes for the observed variation in the particulate absolute concentration north respective south of the ITCZ. The analysis will be based on the data set that was collected during the Ronald H. Brown 1999 cruise, since this cruise contains the largest number of samples.

\section{Variations in the Indian Ocean MBL aerosol}

The RB 1999 particulate and gas samples were classified into different groups according to the appearance of the trajectories. This classification was made independent of the position and date of sampling. Five major groups were identified.

- Large Indian influence (lInd): Trajectories that originated, or passed over, densely populated or industrialized areas in the Indian subcontinent with less than 5 days of transport time since last contact with India or samples with less than 2 days of transport time since last contact with India. Fig. 6a.
- Small Indian influence (sInd): Trajectories that originated, or passed over, densely populated or industrialized places in the Indian subcontinent with more than 5 days of transport time since last contact with India, or trajectories that only passed a short distance over the Indian subcontinent. Fig. 6b.

- Arabian sea (Arab): Trajectories from the Arabian Sea and the surrounding land areas but with no Indian subcontinent contact. Fig. 6c.

- Clean air north of the ITCZ (cleanN): Trajectories with origin over the northern Indian Ocean but with no indication of contact with land during the last seven days. The prevailing arrival direction at the ships was from the north, Fig. $6 \mathrm{~d}$.

- Clean air south of the ITCZ (cleanS): Trajectories with origin over the southern Indian Ocean with no contact with land. The prevailing arrival direction at the ships were from the south, Fig. 6e.

\subsection{Anthropogenic components}

This discussion will focus on samples collected north of the ITCZ according to the conclusion in Sect. 3 where no indication of anthropogenic components were observed south of the ITCZ. Table 2 shows that the samples with trajectories originating over India, (sInd and IInd) showed the highest concentrations of the anthropogenically derived constituents, $\mathrm{nss}-\mathrm{SO}_{4}^{2-}, \mathrm{NH}_{4}^{+}, \mathrm{nss}^{+} \mathrm{K}^{+}$, as well as for the sum of total analyzed fpm mass with nss- $\mathrm{SO}_{4}^{2-}$ and $\mathrm{NH}_{4}^{+}$as the major components. Overall, the concentrations in the sInd group were about half of those in the IInd group. Our results were consistent with source estimations for biomass burning (Galanter et al., 2000), $\mathrm{SO}_{2}$ (Arndt et al., 1997) and $\mathrm{NH}_{4}^{+}$(Bouwman et al., 1997) which indicate large sources in India.

Among the samples collected north of the ITCZ, the samples representing the cleanN group showed the lowest concentrations of anthropogenic constituents, as well as the lowest median total sum.

The observed difference in the anthropogenic constituents between the 1Ind, sInd and cleanN groups was related to the time since last contact with India $\left(T_{\text {Ind }}\right)$ or with any continental area $\left(T_{\text {land }}\right)$, cf. Table 2 . The highest concentrations were associated with a median $T_{\text {Ind }}=52 \mathrm{~h}$ (IInd) and the lowest with a median $T_{\text {land }}>170 \mathrm{~h}$ (cleanN). We attribute the difference to increasing influence of dry deposition losses with increasing time of transport over the Indian Ocean. The influence of wet deposition was probably of marginal influence because large-scale subsidence suppress precipitation during the winter monsoon season over the Indian ocean. Only eight precipitation events were encountered during the Ronald $\mathrm{H}$. Brown cruise in 1999 (Granat et al., 2002), of which four were associated with the ITCZ or south of the ITCZ. 

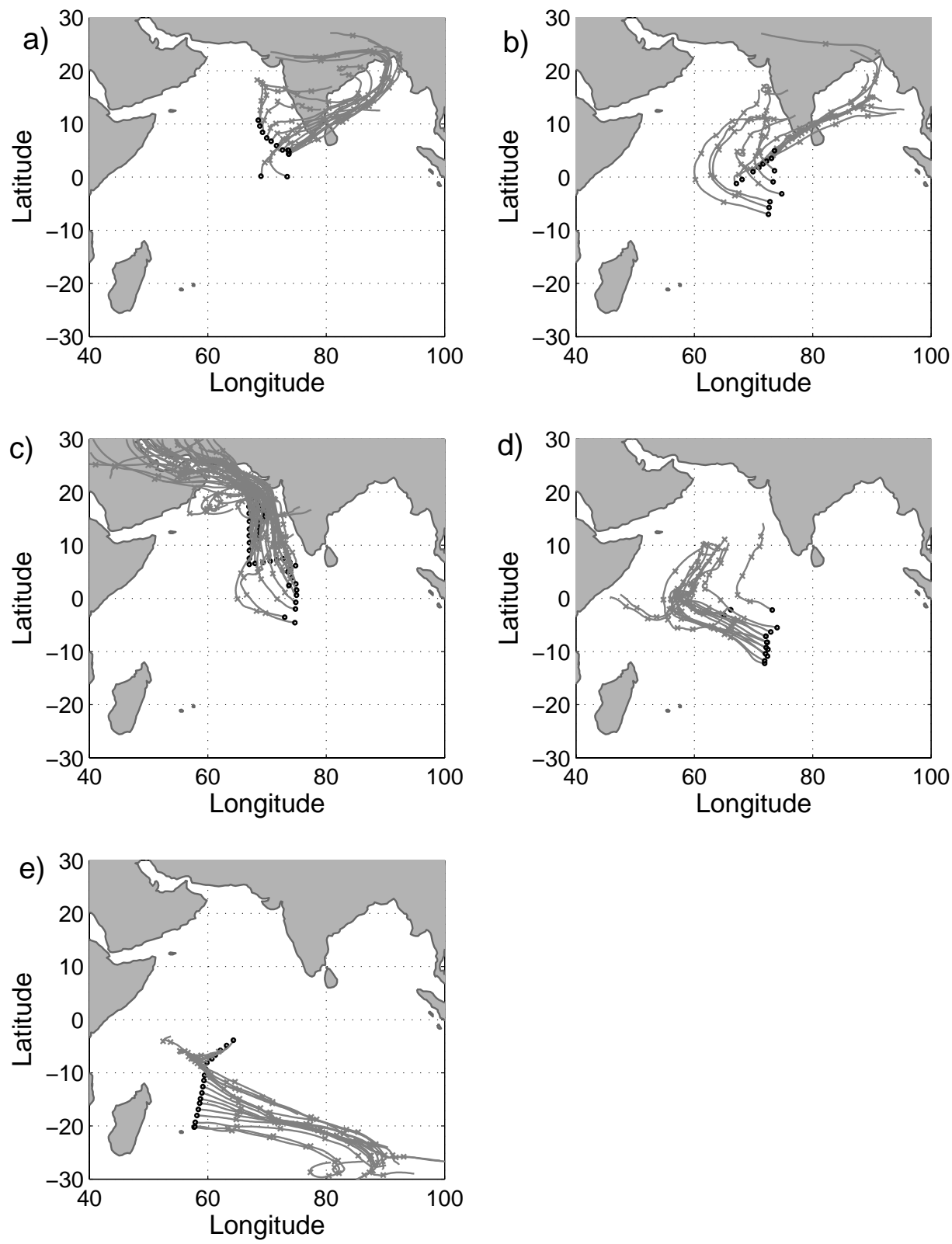

Fig. 6. Trajectories for the Ronald H. Brown 1999 cruise, sorted into different groups according to origin of the air. (a) Large Indian influence (IInd), (b) Small Indian influence (sInd), (c) Arabian sea or surrounding land areas (Arab), (d) Clean air north of the ITCZ with no indication of contact with land (cleanN), (e) Clean air south of the ITCZ (cleanS).

The higher concentration of $\mathrm{SO}_{2}$ south of the ITCZ, (Fig. 5), seems surprising in view of the strong Indian sources of $\mathrm{SO}_{2}$ (Arndt et al., 1997). However, when sorting the $\mathrm{SO}_{2}$ data according to trajectory groups a consistent pattern evolved, Table 2, with the most polluted cases (IInd) showing the highest median $\mathrm{SO}_{2}$ concentrations. Figure 7a shows that the $\mathrm{SO}_{2}$ concentration decreased substantially well before $T_{\text {Ind }}$ equals to $60 \mathrm{~h}$. By comparing the $\mathrm{SO}_{2}$ concentration with the nss- $\mathrm{SO}_{4}^{2-}$ levels, Fig. 7b, a more rapid decrease was observed for $\mathrm{SO}_{2}$ than for nss- $\mathrm{SO}_{4}^{2-}$. The larger loss for
$\mathrm{SO}_{2}$ relative to nss- $\mathrm{SO}_{4}^{2-}$ was probably due to its higher dry deposition rate together with gas to particulate phase oxidation (Langner and Rodhe, 1991). Over the Indian Ocean, as shown in Fig. $7 \mathrm{~b}$ and Table 2, the levels of $\mathrm{SO}_{2}$ were at the most $10 \%$ of the recorded fpm nss- $\mathrm{SO}_{4}^{2-}$ concentrations. The observed variability in fpm nss- $\mathrm{SO}_{4}^{2-}$ over the Indian Ocean north of the ITCZ could therefore not be explained by the observed levels of $\mathrm{SO}_{2}$. We have found no explanation for the $\mathrm{SO}_{2}$ gradient across the ITCZ with highest concentration on the southern side. 

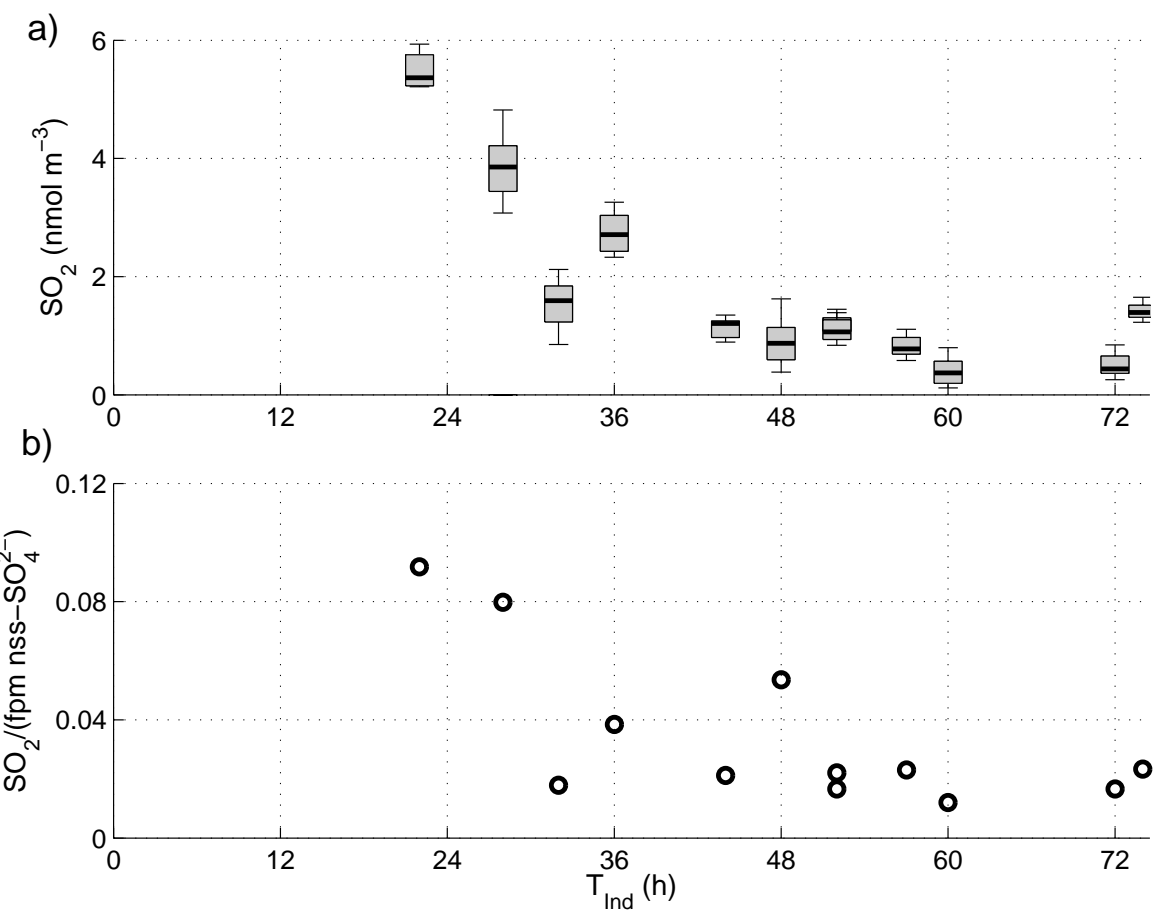

Fig. 7. (a) The $\mathrm{SO}_{2}$ concentration as medians over the aerosol sampling time $(\sim 6 \mathrm{~h})$ as a function of transport time from India during the Ronald H. Brown cruise in 1999. The box includes data between the 25 and 75 percentiles and the vertical bars represent the 10 and 90 percentiles. (b) The $\mathrm{SO}_{2} /\left(\mathrm{fpm} n s s-\mathrm{SO}_{4}^{2-}\right.$ ) molar ratio, as a function of transport time from India during the Ronald $\mathrm{H}$. Brown cruise in 1999.

This analysis shows that the high concentrations of many particulate constituents over the northern Indian Ocean were caused by long range transport from sources on the Indian continent.

\subsection{Soil dust}

The samples with trajectories originating from the Arabian Sea or from the surrounding land areas, Arab, had similar absolute fpm sum as the sInd group. However the former were more enriched by nss- $\mathrm{Ca}^{2+}$. This was also seen in the cpm record (Quinn et al., 2002). The estimated large source area for dust (Tegen and Fung, 1994) in the land areas around the Arabian sea caused the relatively elevated concentrations of nss- $\mathrm{Ca}^{2+}$ compared to the other aerosol constituents. The $\mathrm{Ca}^{2+} / \mathrm{Na}^{+}$molar ratio can be used to indicate the influence of transport of dust from continental sources relative to the local sea salt sources. The observed median fpm $\mathrm{Ca}^{2+} / \mathrm{Na}^{+}$molar ratio in the Arab was higher (0.34) than in the sInd (0.26), indicating a larger soil dust influence in the Arab group. On the other hand, the results relative to the IInd group showed opposite values with both nss-Ca ${ }^{2+}$ levels and $\mathrm{Ca}^{2+} / \mathrm{Na}^{+}$ratio exceeding those of the Arab group. This feature was even more clear in the cpm record (Quinn et al., 2002, personal communication). This is likely to be due to the more limited time since last contact with India (median $T_{\text {Ind }}=52 \mathrm{~h}$ ) compared to the time since last contact with land around the Arabian sea (median $T_{\text {Arab }}=120 \mathrm{~h}$ ) and hence larger influence by deposition during the transport to the ship in the latter group.

\subsection{DMS derived components}

The observed fpm MSA/nss-SO ${ }_{4}^{2-}$ molar ratio in the air south of the ITCZ (cleanS) was on average around 3\%. This is in agreement with other measurements performed in unpolluted air over tropical waters (Bates et al., 1992; Bates et al., 2001; Leck et al., 2002a), and also supported by model calculations (Ayers et al., 1996) at similar temperatures and latitudes as this study. We conclude consistent with Sect. 3 that there was no, or only marginal, influence of continental or anthropogenic sulfur sources south of the ITCZ and that the observed fpm nss- $\mathrm{SO}_{4}^{2-}$ originated from the oxidation of DMS.

A major fraction $(\sim 75 \%)$ of the total particulate MSA in the cleanS samples was associated with the cpm (comparison with data from Quinn et al., 2002). As discussed in Sect. 3, the condensation of MSA seemed to have favored the largest available aerosol surface.

We suggest that the observed variation in $\mathrm{SO}_{2}, \mathrm{nss}_{-} \mathrm{SO}_{4}^{2-}$ and MSA concentrations south of the ITCZ was related to variations in the DMS source, while north of the ITCZ the 
concentrations were also suggested to be dependent on the available aerosol surface areas (as discussed in Sect. 3).

Assuming the nss- $\mathrm{SO}_{4}^{2-}$ south of ITCZ to be representative for biogenic $\mathrm{SO}_{4}^{2-}$ sources over the Indian Ocean, the contribution north of the ITCZ from biogenic sources of the total fpm nss- $\mathrm{SO}_{4}^{2-}$ could be calculated, using the nss- $\mathrm{SO}_{4}^{2-}$ from the cleanS group. This calculation indicated that up to $40 \%$ of the nss- $\mathrm{SO}_{4}^{2-}$ in the cleanN group, $<20 \%$ in Arab and sInd groups, while only a small fraction $(<10 \%)$ in the most polluted cases (IInd group) potentially originated from biogenic sulfur. The same comparison for $\mathrm{SO}_{2}$ showed that a major fraction of the $\mathrm{SO}_{2}$ over the Indian Ocean north of the ITCZ originated form a biogenic source. The only exception was for samples with $T_{\text {Ind }}$ less than $60 \mathrm{~h}$.

The observed variation in $\mathrm{NH}_{4}^{+}$in the cleanS samples was larger than for nss- $\mathrm{SO}_{4}^{2-}$ causing the observed variation in

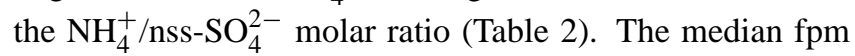
$\mathrm{NH}_{4}^{+} /$nss- $\mathrm{SO}_{4}^{2-}$ molar ratio was 0.3 (Table 2) substantially lower than the value around 1 typically reported elsewhere (Covert et al., 1988; Leck and Persson, 1996) in clean marine areas. Measurements by Huebert et al. (1996) showed a decreasing $\mathrm{NH}_{4}^{+} / \mathrm{nss}-\mathrm{SO}_{4}^{2-}$ molar ratio with increasing particle size. The volume size distribution observed simultaneously with our measurements by Bates et al. (2002) showed the sub-micrometer volume to be shifted towards $1 \mu \mathrm{m}$ diameter, suggesting a low molar ratio. However, the observed values were still lower than those reported by Huebert et al. indicating either a lack of available $\mathrm{NH}_{3}(\mathrm{~g})$ or a chemical composition of the preexisting particles that prevented $\mathrm{NH}_{3}(\mathrm{~g})$ uptake.

\subsection{Sea salt}

Studies in marine areas have observed the logarithm of the sea salt concentrations in the atmosphere (both number and mass) to be in linear relation to the local wind speed due to wave action on the sea surface (O' Dowd et al., 1997; Quinn et al., 2000; Nilsson et al., 2001; Leck et al., 2002b). These relationships were observed for a wide range of particle sizes including sub-micrometer sizes. In this study the average wind speed during the aerosol sampling periods was compared with the observed sea salt mass in the samples. In samples that were not influenced by continental sources (cleanS) the fpm sea salt varied according the local wind speed.

$\log _{10}\left[\mathrm{fpm}\right.$, sea salt, $\left.\mu \mathrm{g} \mathrm{m}^{-3}\right]=0.049 *\left|U, \mathrm{~ms}^{-1}\right|-1.3$

This shows that the local wind speed could explain a major part of the variation in the fpm sea salt $\left(r^{2}=0.6\right)$. The cpm sea salt measured by Quinn et al. (2002, personal communication) showed a similar correlation with the wind speed but with smaller covariation $\left(r^{2}=0.4\right)$.

$\log _{10}\left[\mathrm{cpm}\right.$, sea salt, $\left.\mu \mathrm{g} \mathrm{m}^{-3}\right]=0.043 *\left|U, \mathrm{~ms}^{-1}\right|+0.23(2)$

The lower covariation (both for fpm and cpm) compared to other studies could be related to the relatively low and narrow

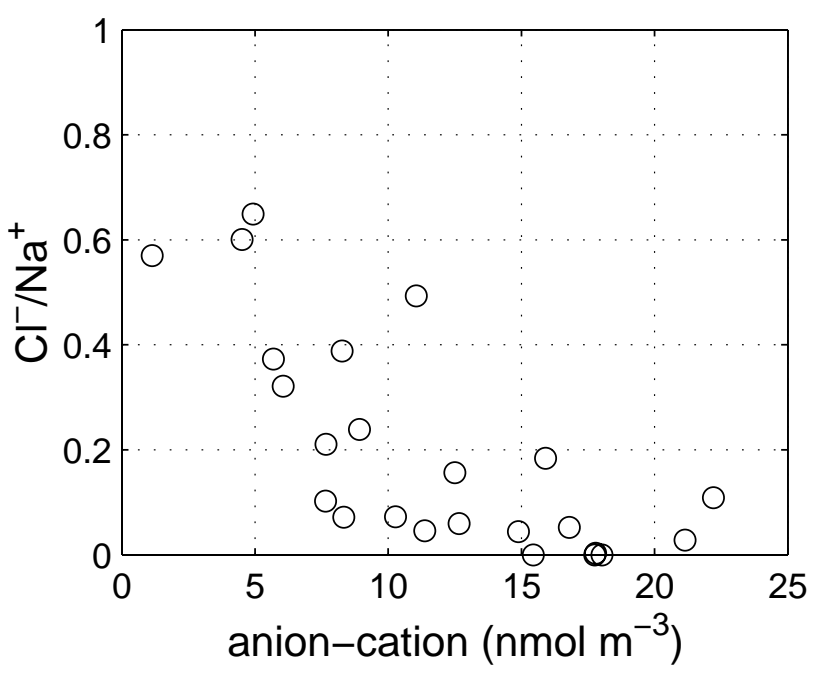

Fig. 8. The fpm $\mathrm{Cl}^{-} / \mathrm{Na}^{+}$molar ratio as a function of the difference between the analysed cations and anions (referred to as acidity) for samples in the IInd and sInd trajectory groups during the Ronald $\mathrm{H}$. Brown cruise in 1999.

range of wind speed $\left(5.6 \pm 2.8 \mathrm{~m} \mathrm{~s}^{-1}\right)$ experienced during INDOEX.

In the air influenced by anthropogenic sources north of the ITCZ no significant covariation $\left(r^{2}<0.2\right)$ with the local wind speed was observed, neither for fpm or the cpm. A MBL affected by anthropogenic or continental sources has been reported to contain a modified sea salt distribution. Elevated concentrations of $\mathrm{Cl}^{-}$and $\mathrm{Na}^{+}$have been found in particulate and precipitation samples from the Indian continent (Kulshrestha et al., 1995; Norman et al., 2001) indicating other potential sources than the ocean, probably soil dust. This is consistent with this study, showing that the fpm $\mathrm{Na}^{+}$concentrations were slightly elevated in the samples with short time since last contact with land (Arab and IInd), cf. Table 2. Similar results were observed for the cpm sea salt by Quinn et al. (2002, personal communication).

The acidity of the particles also affects the sea salt concentration by a loss of $\mathrm{Cl}^{-}$increasing towards low $\mathrm{pH}$. The $\mathrm{Cl}^{-} / \mathrm{Na}^{+}$molar ratio of sea salt particles has been observed to decrease with increasing particle acidity from the molar ratio of pure sea water sodium chloride $(\mathrm{NaCl})$ of 1.17 (Keene et al., 1998). To investigate the importance of an increased acidity for the $\mathrm{Cl}^{-}$depletion, we used the calculated difference between the sum of equivalent concentration of analyzed anions and cations as an indication for level of "acidity" in the samples. In Fig. 8 it is shown that, for the fpm samples collected north of the ITCZ, an increasing "acidity" resulted in more depletion of chloride, with molar ratios below 0.2 for samples with highest "acidity". Also the median ratio for the different trajectory groups varied in this way with $\mathrm{Cl}^{-} / \mathrm{Na}^{+}$molar ratios of around 0.6 in the cleanN group and then decreasing to 0.13 in the sInd and to 0.06 in 
the IInd. This in agreement with the increasing level of pollution. The absence of anthropogenic influence $\left(\mathrm{SO}_{4}^{2-}\right)$ in the cleanS samples strongly reduced the particle acidity and the median fpm $\mathrm{Cl}^{-} / \mathrm{Na}^{+}$molar ratio was 1.0 in the cleanS group, showing only small depletion of $\mathrm{Cl}^{-}$. In general only marginal depletion $\left(\mathrm{Cl}^{-} / \mathrm{Na}^{+}\right.$molar ratio above 1$)$ was observed in the cpm, probably due to an absence of "acididity" on the larger sizes.

We conclude that the variation in the observed levels of sea salt components (fpm+cpm) south of the ITCZ was dependent on the local wind speed, while the observed sea salt concentration north of the ITCZ was found to be influenced by contribution from continental sources and also to the depletion of $\mathrm{Cl}^{-}$(fpm).

\subsection{Relative chemical composition}

The relative chemical composition collected during the $\mathrm{RB}$ 1999 cruise north of the ITCZ (Fig. 9a and Table 2) was remarkable constant despite the differences in absolute concentration. The relative chemical composition was dominated by $\mathrm{NH}_{4}^{+}$and nss-SO $\mathrm{S}_{4}^{2-}$ with a slightly larger contribution from $\mathrm{NH}_{4}^{+}$. The contributions from nss-K $\mathrm{K}^{+}$and the sum of the sea salt components were small with the remaining components negligible. In general, the relative chemical composition south of the ITCZ showed larger variation than north of the ITCZ (Fig. 9b and Table 2). The relative chemical composition south of the ITCZ was dominated by nss- $\mathrm{SO}_{4}^{2-}$ with the sum of the sea salt components and $\mathrm{NH}_{4}^{+}$as other major components.

\section{Interannual variation in the Indian Ocean MBL sub- micrometer aerosol}

The measurements of fpm during both INDOEX FFP 1998 and IFP 1999 gave us a possibility to compare not only the variation between 1998 and 1999 but also two separate efforts during 1999 (spatial and temporal variation).

The relative chemical composition from the Sagar Kanya cruises (1998 and 1999) agreed with that from the RB 1999 within $10 \%$ for the major components. In general, the relative chemical composition south of the ITCZ showed larger variation than north of the ITCZ during all cruises, but with the same major components.

A comparison of absolute concentrations during the three cruises, divided into the trajectory groups cleanS, Arab, sInd and IInd, is shown in Fig. 10. The variation between the trajectory groups for the Sagar Kanya cruises exhibited the same general pattern as for the RB 1999 data set. This indicates that the same processes causing the variation in concentration and chemical composition within the RB 1999 data set, as presented in Sect. 4, also apply for both the SK 1998 and the SK 1999 data sets.
However, there were several distinct differences in the absolute concentrations between the data sets. In general, higher concentrations of all constituents occurred during RB 1999, in all trajectory groups, than during SK 1998. For some constituents (total sum and $\mathrm{NH}_{4}^{+}$) this also applied for SK 1999 in comparison to SK 1998. However, large differences in absolute concentrations were also observed between the RB 1999 and SK 1999 cruises. In order to seek causes for the interannual variation as well as the variation between the two 1999 cruises, we investigated the variation in source and sink strength, the location of the source area and time the air spent over the Indian Ocean since last contact with the Arabian and Indian coast.

The absolute concentrations of the anthropogenic and continental constituents were observed to be substantially higher (2-4 times) in the IInd and sInd groups during the RB 1999 cruise compared to the SK 1998. In the case of IInd, the median time of transport since last contact with India was found to be longer $\left(T_{\text {Ind }}=110 \mathrm{~h}\right)$ during the SK 1998 cruise compared to the 1999 cruises $\left(T_{\text {Ind }}=50\right.$ and $60 \mathrm{~h}$ for RB 1999 and SK 1999, respectively). The shorter transport times in 1999 were associated with strong northeasterly flow over the Indian continent in February and March 1999 (Verver et al., 2001; Rasch et al., 2001). The potentially larger deposition losses in 1998 are likely to have contributed to the lower concentrations during the SK 1998 cruise.

The concentration of soil dust (nss- $\mathrm{Ca}^{2+}$ ) was found to be more than twice as high in the Arab samples during the RB 1999 cruise than during the SK 1999 and SK 1998 cruises. The RB 1999 Arab samples were collected during March 1999 and during that month unusually strong outflow from the dry areas around the northern Arabian Sea was observed (Verver et al., 2001). Model studies of the soil dust over the Arabian Sea by Rasch et al. (2001) also showed elevated concentrations during March 1999 in contrast to both February 1999 (mainly the sampling period for Arab during SK 1999) and March 1998 (sampling period for SK 1998). This could thus possibly explain the higher nss- $\mathrm{Ca}^{2+}$ concentrations in the Arab group during RB 1999.

Although the data showed some differences, both between 1998 and 1999 and between the two 1999 cruises, which we were not able to explain, we believe that the conclusions in Sect. 4 are valid for each data set. We conclude that variations in source strength, source area and time of transport over the Indian Ocean are important contributions to the variations in concentration.

\section{Conclusions}

The water soluble inorganic part of the sub-micrometer aerosol was measured from two research vessels over the Indian Ocean during the winter monsoon season (February to March) within the frames of the INDOEX project during 1998 and 1999. Additional measurements of the gas phase 

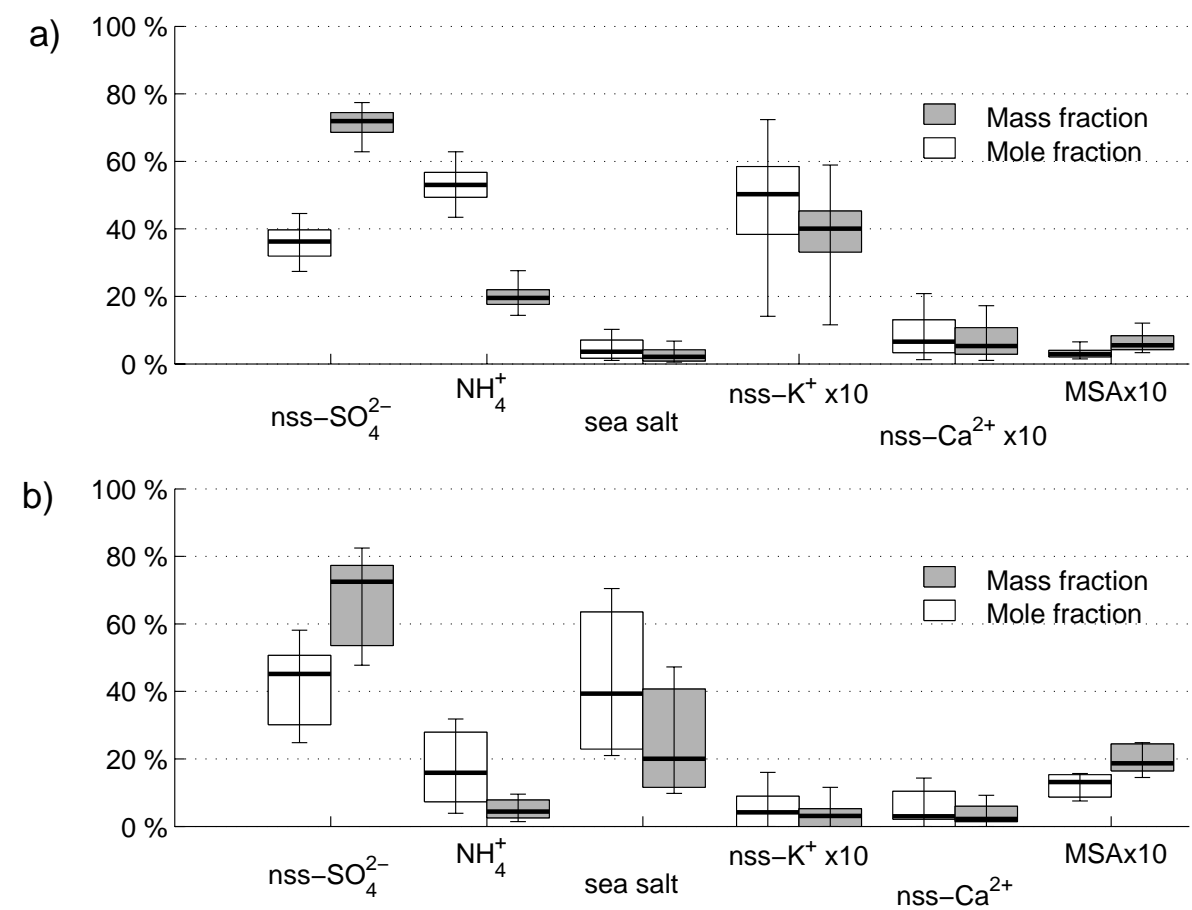

Fig. 9. The median molar and mass fractions (thick horizontal line) of the analysed components for the Ronald H. Brown 1999 cruise, (a) north of the ITCZ, median $3.2 \mu \mathrm{g} \mathrm{m}^{-3}$ total analysed mass, (b) south of the ITCZ, median $0.5 \mu \mathrm{g} \mathrm{m}^{-3}$ total analysed mass. The box includes data between the 25 and 75 percentiles and the vertical bars represent the 10 and 90 percentiles.

$\mathrm{SO}_{2}$ were performed from one research vessel during the INDOEX IFP 1999.

One of the main goals of this study was to investigate the role of the ITCZ for the transport of MBL aerosol and $\mathrm{SO}_{2}$. We found the ITCZ to be an effective barrier for sub-micrometer particles in the MBL with no indication of transport across the ITCZ. Irrespective of the latitudinal position of the ITCZ all samples collected north of the ITCZ were found to be influenced by anthropogenic and continental sources with 6-16, 20-80 and $>40$ times higher concentrations than south of the ITCZ for nss- $\mathrm{SO}_{4}^{2-}, \mathrm{NH}_{4}^{+}$and nss$\mathrm{K}^{+}$, respectively. There was no, or only marginal, influence of continental or anthropogenic nss- $\mathrm{SO}_{4}^{2-}$ south of the ITCZ and the variation in concentration was attributed to variation in the marine biogenic sources. The contribution from marine biogenic sources to the fpm nss-SO $\mathrm{SO}_{4}^{2-}$ north of the ITCZ was estimated to be up to $40 \%$ in clean air but less than $10 \%$ in polluted air originating from India.

MSA showed surprisingly a similar variation with higher absolute fpm concentration in the polluted air north of the ITCZ as the anthropogenic constituents. South of the ITCZ $\sim 75 \%$ of the total MSA was associated with the cpm aerosol, while north of the ITCZ the MSA almost completely was found on the fpm particles. The distribution of the aerosol surface area available for the condensation of gaseous MSA into particulate phase was suggested to be the reason for this variation.
The observed concentrations of $\mathrm{SO}_{2}$ were observed to be higher south of the ITCZ. Only samples with time since last contact with India less than $60 \mathrm{~h}$ showed a noticeable anthropogenic influence. The $\mathrm{SO}_{2}$ concentrations made up for at the most $10 \%$ of the observed sub-micrometer nss- $\mathrm{SO}_{4}^{2-}$ north of the ITCZ. We conclude that the observed variation in fpm nss- $\mathrm{SO}_{4}^{2-}$ over the Indian Ocean north of the ITCZ could not be explained by the locally observed levels of $\mathrm{SO}_{2}$.

The sea salt concentration in aerosols south of the ITCZ was found to be somewhat dependent on the local wind speed. However, north of the ITCZ the variation was mainly related to the depletion of chloride in correlation with calculated particle acidity, but also with some indication of contribution from continental sources.

The variation in total analyzed sub micrometer concentrations north of the ITCZ was interpreted in terms of variations in source region, source strength and time of transport over the Indian Ocean. One of the main reasons for the observed differences in anthropogenic constituents, seemed to be the variation in deposition losses due to different time of transport over the Indian Ocean. The highest concentrations were associated with the shortest time since last contact with India.

The soil dust concentration was enriched in samples with trajectories originating over land areas around the Arabian Sea. Highest concentrations were observed in March 1999 during a period with observed unusual strong outflow from land areas north of the Arabian Sea. 
a)
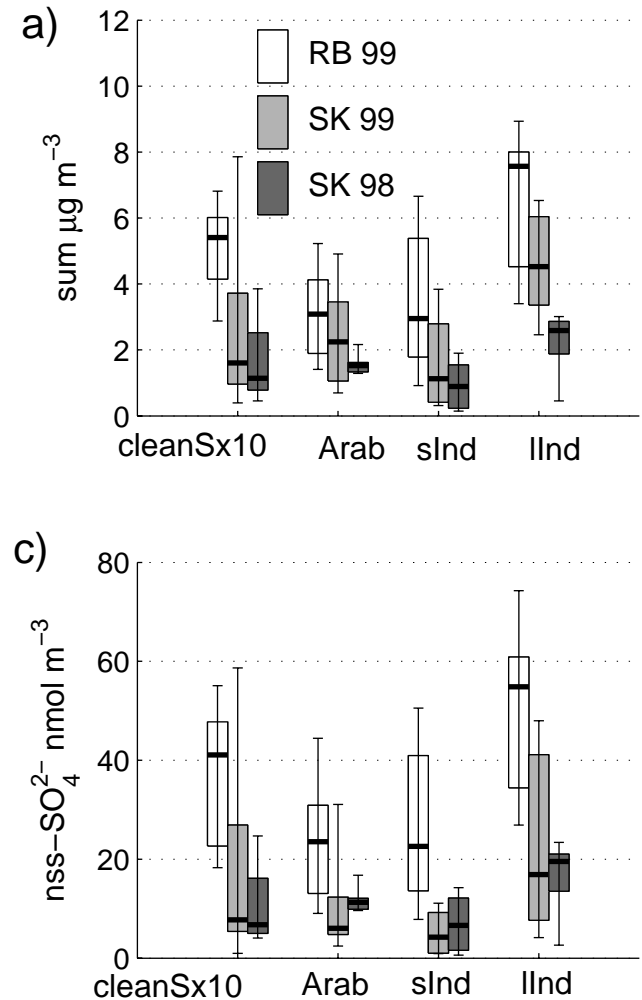
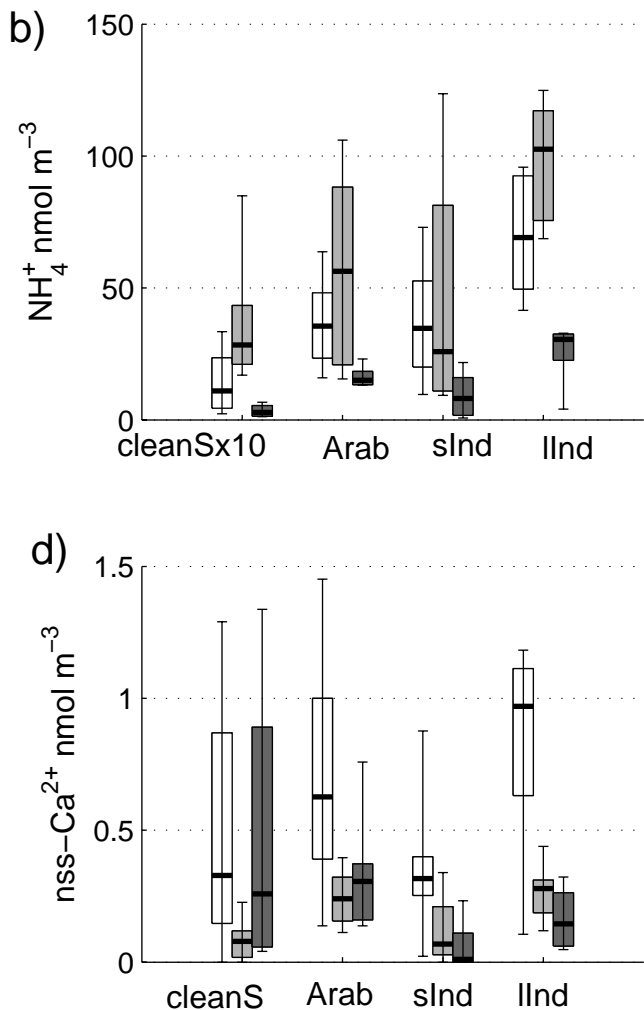

Fig. 10. The median concentrations (thick horizontal line) for the three cruises divided into different trajectory groups. (a) fpm sum, (b) $\mathrm{NH}_{4}^{+}$, (c) nss-SO $\mathrm{SO}_{4}^{2-}$, (d) nss-Ca ${ }^{2+}$. The box includes data between the 25 and 75 percentiles and the vertical bars represent the 10 and 90 percentiles.

Acknowledgements. This project was founded by the Swedish Science Research Council under contract No. G 5103-1238/1999. Special thanks to Umesh Kulshrestha for performing the sampling on board the Sagar Kanya. The help from the NOAA PMEL group is greatly appreciated. Scientist from PMEL performed a large fraction of the chemical analysis and provided extensive technical support on board the Ronald H. Brown. Special thanks to Patricia Quinn for providing the cpm data and for useful comments of an early version of the manuscript.

\section{References}

Arndt, R. L., Carmichael, G. R., Streets, D. G., and Bhatti, N.: Sulfur dioxide emissions and sectoral contribution to sulfur deposition in Asia, Atmos. Environ., 31, 1553-1572, 1997.

Ayers, G. P., Cainey, J. M., Granek, H., and Leck, C.: Dimethylsulfide oxidation and the ratio of methansulfonate to non seasalt sulfate in the marine aerosol, J. Atmos. Chem., 25, 307-325, 1996.

Ball, W. P., Dickerson, R. R., Doddridge, B. G., Stehr, J., Miller, T., Savoie, D., and Carsey, T.: Bulk and size-segregated aerosol composition observed during INDOEX 1999: Overview of meteorology and continental impacts, J. Geophys. Res., in press, 2003.
Bates, T. S., Calhoun, J. A., and Quinn, P. K.: Variations in the methansulfonate to sulfate molar ratio in submicrometer marine aerosol particles over the south Pacific Ocean, J. Geophys. Res. 9, 9859-9865, 1992.

Bates, T. S., Quinn, P. K., Coffman, D. J., Johnson, J. J., Miller, T. L., Covert, D. S., Wiedensohler, A., Leinert, S., Nowak, A., and Neusüss, C.: Regional physical and chemical properties of the marine boundary layer aerosol across the Atlantic during Aerosols99: An overview, J. Geophys. Res. 106, 20 767-20 782, 2001.

Bates, T. S., Coffman, D. J., Covert D. S., and Quinn, P. K.: Regional marine boundary layer aerosol size distribution in the Indian, Atlantic and Pacific Oceans: A comparison of INDOEX measurements with ACE-1, ACE-2, and Aerosols99, J. Geophys. Res., 107(D19), doi:10.1029/2001JD001174, 2002.

Bouwman, A. F., Lee, D. S., Asman, W. A. H., Dentener, F. J., Van der Hoek, K. W., and Olivier, J. G. J.: A global high resolution emission inventory for ammonia, Global Biogeochemical Cycles, 11, 561-587, 1997.

Cantrell, W., Shaw, G., Leck, C., Granat, L., and Cachier, H.: Relationships between cloud condensation nuclei spectra and aerosol particles on a south-north transect of the Indian Ocean, J. Geophys. Res., 105, 15313-15320, 2000.

Charlson, R. J., Schwartz, S. E., Hales, J. M., Cess, R. D., Coakley, J. A., Hansen, J. E., and Hofmann, D. J.: Climate forcing by anthropogenic aerosols, Science, 255, 423-430, 1992. 
Covert, D. S.: North Pacific marine background aerosol: average ammonium to sulfate ratio equals 1, J. Geophys. Res., 93, 84558458, 1988.

Draxler, R. R.: Hybrid single-particle lagrangian integrated trajectories (HY-SPLIT): Version 3.0. User's guide and model description, Tach. Rep. ERL ARL-195, NOAA, Silver Springs, Md., 1992.

Galanter, M., Levy II, H., and Carmichael, G. R.: Impact of biomass burning on tropospheric $\mathrm{CO}, \mathrm{NO}_{\mathrm{x}}$ and $\mathrm{O}_{3}$, J. Geophys. Res., 105, 6633-6653, 2000.

Granat, L., Norman, M., Leck, C., Kulshrestha, U. C., and Rodhe, H.: Wet scavenging of sulfur compounds and other constituents during the Indian Ocean Experiment (INDOEX), J. Geophys. Res., 107(D19), doi:10.1029/2001JD000499, 2002.

Huebert, B. J., Zhuang, L., Howell, S., Noone, K., and Noone, B.: Sulfate, nitrate, methansulfonate, chloride, ammonia, and sodium measurement from ship, island, and aircraft during the Atlantic Stratocumulus Transition Experiment/Marine Aerosol Gas Exchange, J. Geophys. Res., 101, 4413-4423, 1996.

Intergovernmental Panel on Climate Change (IPCC) 2001: The scientific basis, (Eds) Hougthon, J. T., Ding, Y., Griggs, D. J., Noguer, M., van der Linden, P. J., and Xiaosu D., Cambridge University Press, Cambridge, UK, 2001.

Keene, W. C., Sanders, R., Pzenny, A. A. P., Vogt, R., Crutzen, P. J., and Galloway, J. N.: Aerosol pH in the marine boundary layer: A review and model evaluation, J. Aerosol Sci., 29, 339-356, 1998.

Kerminen V. M. and Leck, C.: Sulfur chemistry over the central Arctic Ocean during the summer: Gas-to-particle transformation, J. Geophys. Res., 106, 32 087-32 099, 2001.

Kulshrestha, U. C., Kumar, N., Saxena, A., Khare, P., Kumari, K. M., and Srivastava, S. S.: Chemical composition of atmospheric aerosol at three representative sites in Agra, Energy Environ. Monitor, 11, 177-181, 1995.

Landsberg, H. E., World survey of climatology, Vol 15, Climates of the Oceans, Edited by H. van Loon, Elsevier Science Publishers B. V., 1984.

Langner, J. and Rodhe, H.: A global three-dimensional model of the tropospheric sulfur cycle, J. Atmos. Chem., 13, 225-263, 1991.

Leck, C. and Persson, C.: Seasonal and short-term variability in dimethyl sulfide, sulfur dioxide and biogenic sulfur and sea salt aerosol particles in the arctic marine boundary layer during summer and autumn, Tellus, 48B, 272-299, 1996.

Leck, C., Heintzenberg, J., and Engardt, M.: A meridional profile of the chemical composition of submicrometer particles over the East Atlantic Ocean: Regional and hemispheric variabilities, Tellus, 54B, 377-394, 2002a.

Leck, C., Norman, M., Bigg, E. K., and Hillamo, R.: Chemical composition and sources of the high arctic aerosol relevant for cloud formation, J. Geophys. Res., 107(DX) doi:10.1029/2001JD001463, 2002b.

Lelieveld, J., Crutzen, P. J., Ramanathan, V., Andreae, M. O., Brenninkmeijer, C. A. M., Campos, T., Cass, G. R., Dickerson, R. R., Fischer, H., de Gouw, J. A., Hansel, A., Jefferson, A., Kley, D., de Laat, A. T. J., Lal, S., Lawrence, M. G., Lobert, J. M., MayolBracero, O. L., Mitra, A. P., Novakov, T., Oltmans, S. J., Prather, K. A., Reiner, T., Rodhe, H., Scheeren, H. A., Sikka, D., and Williams, J.: The Indian Ocean Experiment: Widespread air pollution from South and Southeast Asia, Science, 291, 1031-1036, 2001.

Leon, J. F., Chazette, P., Dulac, F., Pelon, J., Flamant, C., Bonaz- zola, M., Foret, G., Alfaro, S. C., Cashier, H., Cautenet, S., Hamonou, E., Gaudichet, A., Gomes, L., Rajot, J.-L., Lavenu, F., Inamdar, S. R., Sarode, P. R., and Kadadevarmath, J. S.: Largescale advection of continental aerosols during INDOEX, J. Geophys. Res., 106, 28 427-28 439, 2001.

McGrath, R.: Trajectory models and their use in the Irish meteorological service, Memorandum No. 112/89, Irish Meteorological Service, Dublin, 1989.

Mitra, A. P.: INDOEX (India): Introductory note, Current Science, 76, 886-889, 1999.

Neusüss, C. T., Plewka, G. A., Hermann, H., and Quinn, P. K.: Carbonaceous aerosol over the Indian Ocean: OC/EC fraction and speciation from samples taken on board the R/V Ronald $\mathrm{H}$. Brown, J. Geophys. Res., 107(DX), doi:10.1029/2001JD000327, 2002.

Nilsson, E. D., Rannik, Ü., Swietlicki, E., Leck, C., Aalto, P. P., Zhou, J., and Norman, M.: Turbulent aerosol fluxes over the Arctic Ocean, part II: Wind driven sources from the sea, J. Geophys. Res., 106, 32 139-32 154, 2001.

Norman, M., Das, S. N., Pillai, A. G., Granat, L., and Rodhe, H.: Influence of air mass trajectories on the chemical composition of precipitation in India, Atmos. Environ., 35, 4223-4235, 2001.

O'Dowd, C. D., Smith, M. H., Consterdine, I. E., and Lowe, J. A.: Marine aerosol, sea-salt, and the marine sulphur cycle: A short review, Atmos. Environ., 31, 73-80, 1997.

Quinn, P. K. and Bates, T. S.: Collection efficiencies of a tandem sampling system for atmospheric aerosol particles and gaseous ammonia and sulfur dioxide, Environ. Sci. Technol., 23, 736739, 1989.

Quinn, P. K., Asher, W. E., and Charlson, R. J.: Equilibrium of the marine multiphase ammonia system, J. Atmos. Chem., 14, 1130, 1992.

Quinn, P. K., Coffman, D. J., Kapustin, V. N., and Bates T. S.: Aerosol optical properties in the marine boundary layer during the First Aerosol Characterization Experiment (ACE 1) and the underlying chemical and physical aerosol properties. J. Geophys. Res., 103, 16 547-16 563, 1998.

Quinn, P. K., Bates, T. S., Miller, T. L., Coffman, D. J., Johnson, J. E., Harris, J. M., Ogren, J. A., Forbes, G., Anderson, T. L., Covert, D. S., and Rood, M. J.: Surface submicron aerosol chemical composition: What fraction is not sulfate?, J. Geophys. Res., 105, 6785-6805, 2000.

Quinn, P. K., Coffman, D. J., Bates, T. S., Miller, T. L., Johnson., J. E., Voss, K., Welton, E. J., and Neusüss, C.: Dominant aerosol chemical components and their contribution to extinction during the Aerosols 99 cruise across the Atlantic, J. Geophys. Res., 106, 20 783-20 809, 2001.

Quinn, P. K., Coffman, D. J., Bates, T. S., Miller, T. L., Johnson, J. E., Welton, E. J., Miller, M., and Sheridan, P. J.: Aerosol optical properties during INDOEX 1999: Means, variability, and controlling factors, J. Geophys. Res., 107(D19), doi:10.1029/2000JD000037, 2002.

Ramanathan, V., Coakley, J. A., Clarke, A., Collins, W. D., Crutzen, P. J., Dickerson, R., Fahey, D., Gandrud, B., Heymsfield, A., Kiehl, J. T., Krishnamurti, T., Kuettner, J., Lubin, D., Maring, H., Ogren, J., Prospero, J., Rasch, P. J., Savoie, D., Shaw, G., Tuck, A., Valero, F. P. J., Woodbridge, E. L., and Zhang, G.: Indian Ocean Experiment (INDOEX), A multi-agency proposal for field experiments in the Indian Ocean, Publ. 162, Scripps Inst. 
of Oceanogr., La Jolla, Calif., 1996.

Ramanathan, V., Crutzen, P. J., Lelieveld, J., Mitra, A. P., Althausen, D., Anderson, J., Andreae, M. O., Cantrell, W., Grass, G. R., Chung, C. E., Clarke, A. D., Coakley, J. A., Collins, W. D., Conant, W. C., Dulac, F., Heintzenberg, J., Heymsfield, A. J., Holben, B., Howell, S., Hudson, J., Jayaraman, A., Kiehl, J. T., Krishnamurti, T. N., Lubin, D., McFarquhar, G., Novakov, T., Ogren, J. O., Podgorny, I. A., Prather, K., Priestley, K., Prospero, J. M., Quinn, P. K., Rajeev, K., Rasch, P., Rupert, S., Sadourny, R., Satheesh, S. K., Shaw, G. E., Sheridan, P., and Valero, F. P. J.: Indian Ocean Experiment: An integrated analysis of the climate forcing and effect of the great Indo-Asian haze, J. Geophys. Res., 106, 28 371-28 398, 2001.

Rasch P. J., Collins, W. D., and Eaton, B. E.: Understanding the Indian Ocean Experiment (INDOEX) aerosol distribution with an aerosol assimilation, J. Geophys. Res., 106, 7337-7355, 2001.

Reiner, T., Sprung, D., Jost, C., Gabriel, R., Mayol-Bracero, O. L., Andreae, M. O., Campos, T. L., and Shetter, R. E.: Chemical characterization of pollution layers over the tropical Indian Ocean: Signatures of emissions from biomass and fossil fuel burning, J. Geophys. Res., 106, 28 497-28 510, 2001

de Reus, M., Krejci, R., Williams, J., Fisher, H., Schelle, R., and Ström, J.: Vertical and horizontal distribution of the aerosol number concentration and the size distribution over the northern Indian Ocean, J. Geophys. Res., 106, 28 629-28 641, 2001

Saltzman, E. S., Savoie, D. L., Zika, R. G., and Prospero, J. M.: Methane Sulfonic Acid in the Marine Atmosphere, J. Geophys. Res., 88, 10 897-10 902, 1983.

Saltzman, E. S., Yvon, S. A., and Matrai, P. A.: Low-level atmospheric sulfur dioxide measurement using HPLC/Fluorescence detection, J. Atmos. Chem., 17, 73-90, 1993.

Saxena, V. K.: Evidence of biogenic nuclei involvement in Antarctic coastal clouds. J. Phys, Chem., 87, 4130-4134, 1983

Sprung, D., Jost, C., Reiner, T., Hansel, A., and Wisthaler, A.:
Acetone and acetonitril in the tropical Indian Ocean boundary layer and free troposphere: Aircraft based intercomparison of AP-CIMS and PTR-MS measurements, J. Geophys. Res., 106, 28 511-28 527, 2001

Stehr, J. W., Ball, W. P., Dickerson, R. R., Doddridge, B. G., Piety, C. A., and Johnson, J. E.: Latitudinal gradients in $\mathrm{O}_{3}$ and CO during INDOEX 1999, J. Geophys. Res., 107(DX) doi:.10.1029/2001JD000446, 2002.

Tegen, I. and Fung, I.: Modeling of mineral dust in the atmosphere: Sources, transport, and optical thickness, J. Geophys. Res., 99 22 897-22 914, 1994.

Twomey, S. A.: Pollution and the planetary albedo, Atmos. Environ., 8, 1251-1256, 1974.

Verver, G. H. L., Sikka, D. R., Lobert, J. M., Strossmeister, G., and Zachariasse, M.: Overview of the meteorological conditions and atmospheric transport processes during INDOEX 1999, J. Geophys. Res., 106, 28 399-28 413, 2001.

Wagner, V., Schiller, C., and Fisher, H.: Formaldehyde measurements in the marine boundary layer of the Indian Ocean during the 1999 INDOEX cruise of the R/V Ronald H. Brown, J. Geophys. Res., 106, 28 529-28 538, 2001

Welton, E. J., Voss, K. J., Quinn, P. K., Flatau, P. J., Markowicz, K., Campbell, J. R., Spinhirne, J. D., Gordon, H. R., and Johnson, J. E.: Measurements of aerosol vertical profiles and optical properties during INDOEX 1999 using micro-pulse lidars, J. Geophys. Res., 107(DX) doi:10.1029/2000JD000038, 2002.

Wilson, T. R. S., Salinity and major elements of sea water, In: J.P Riley and G. Skirrow (Editors), Chemical Oceanography, 2nd ed. Academic Press, Orlando, FL, 365-413, 1975.

Wisthaler, A., Hansel, A., Dickerson, R. R., and Crutzen, P. J.: Organic trace gas measurements by PTR-MS during INDOEX 1999, J. Geophys. Res., doi:10.1029/2001JD000576, 2002.

Yin, F., Grosjean, D., and Seinfeld, J. H.: Photooxidation of dimethyl sulfide and dimethyl disulfide. I: Mechanism development, J. Atmos. Chem., 11, 309-364, 1990. 